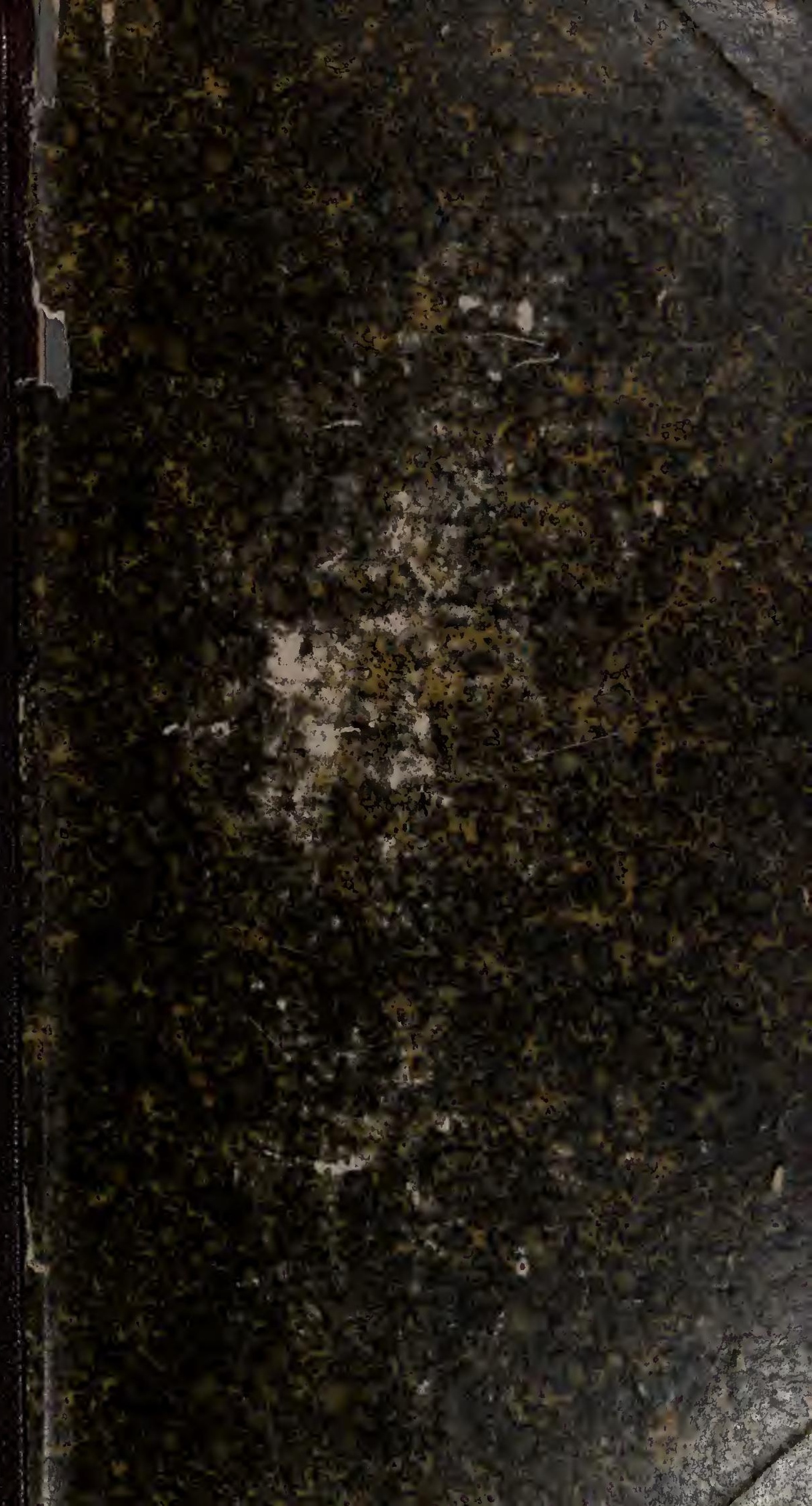



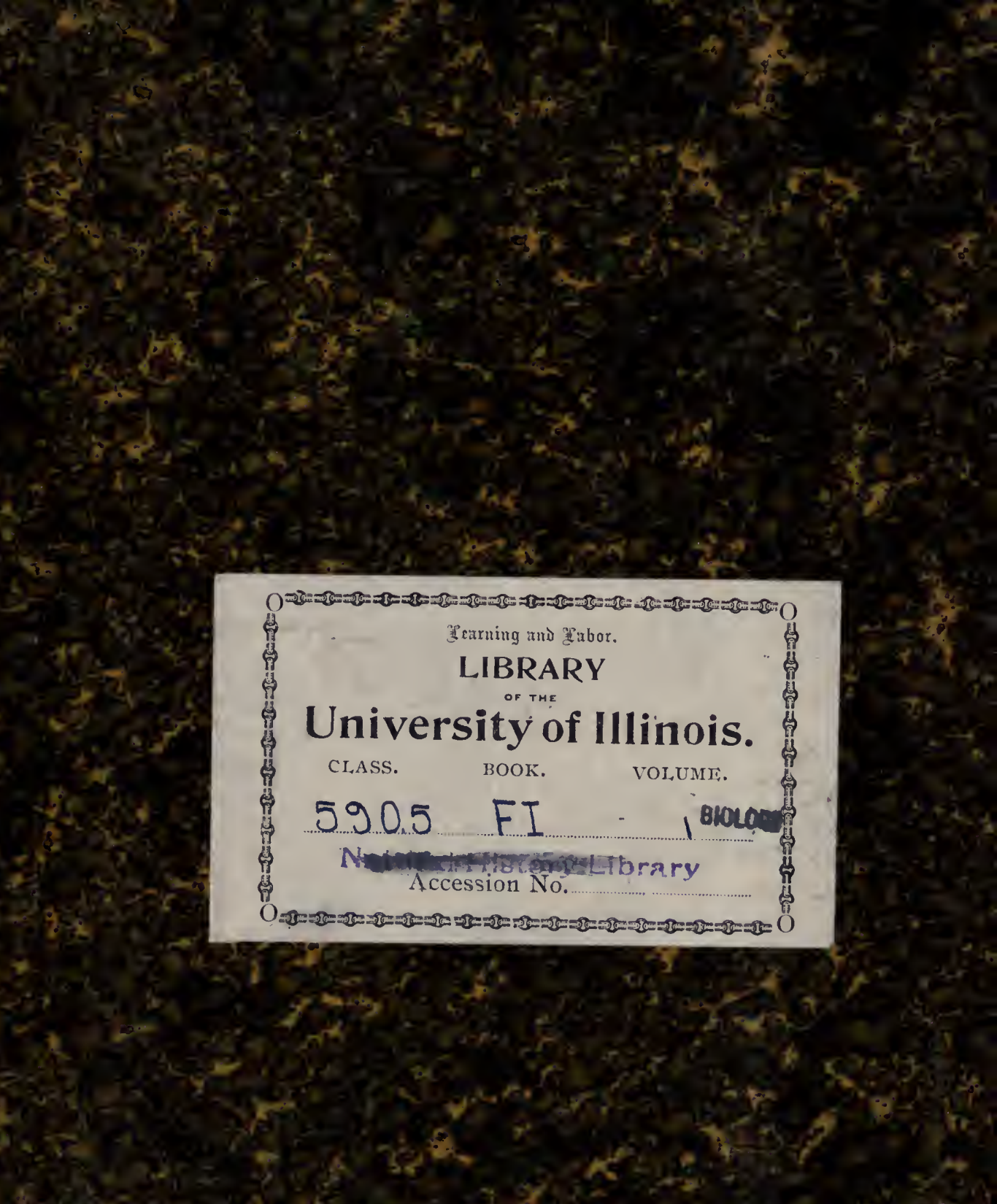

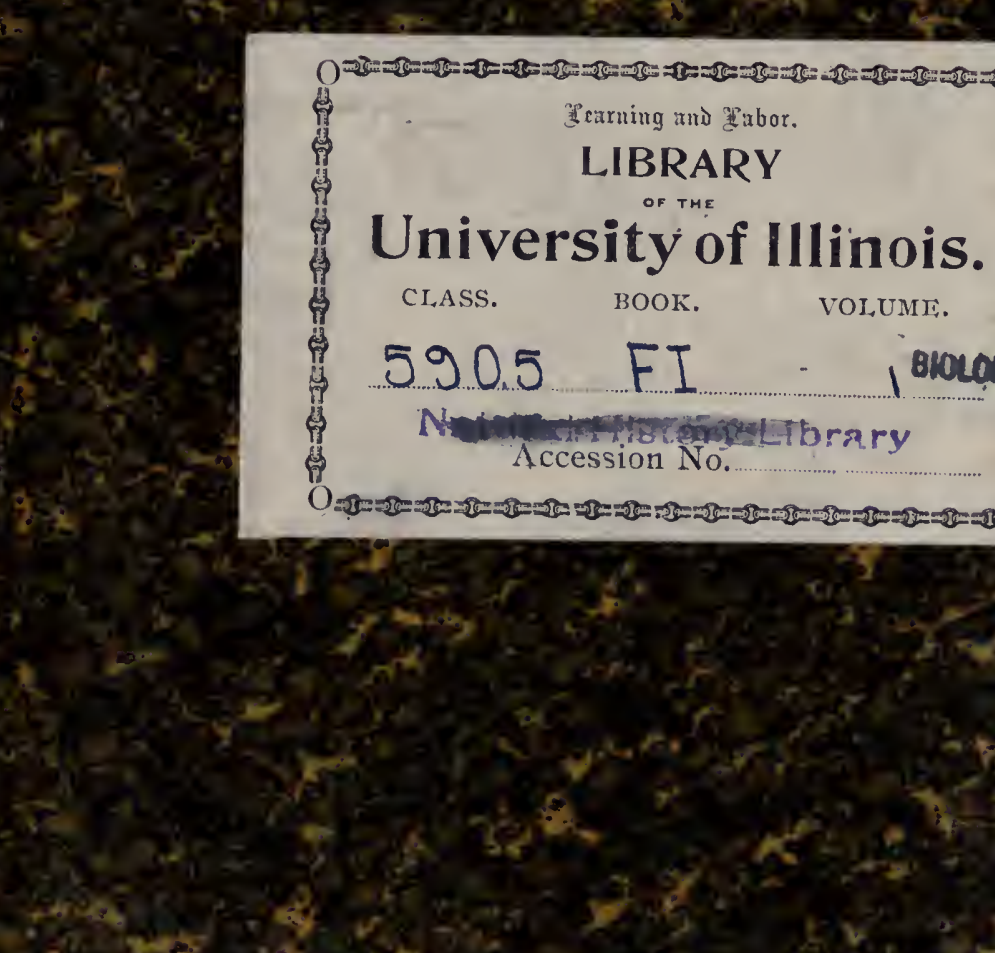

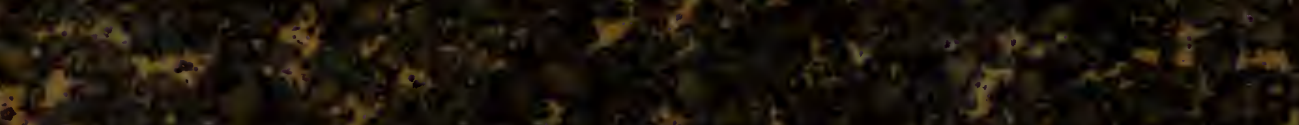
S

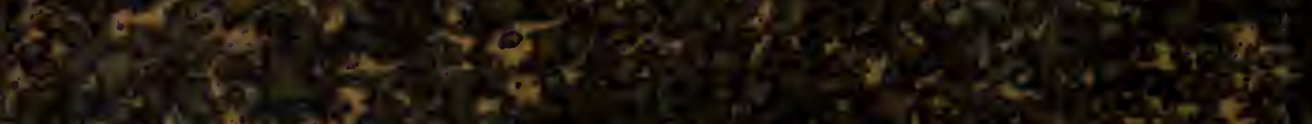
(2)

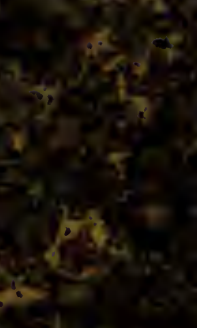








\author{
Field Columbian Museum \\ Publication 32. \\ Zoological Series. \\ Vol. I, No. I3.
}

\title{
CATALOGUE OF MAMMALS
}

FROM THE

\section{OLYMPIC MOUNTAINS}

IVASHINGTON

WITH DESCRIPTIONS OF NEW SPECIES

D. G. Elliot, F.R.S.E., CURATOR OF DEPARTMENT.

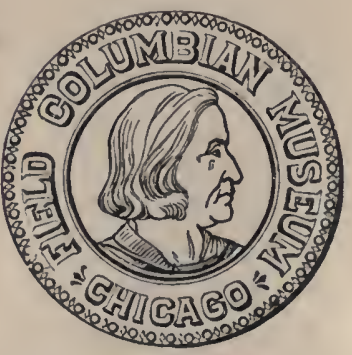

Chicago, U. S. A. March, I899. 



\section{LIST OF MAMMALS OBTAINED IN THE EXPEDITION TO THE OLYMPIC MOUNTAINS, WASHINGTON, 1898.-BY D. G. ELLIOT, F. R. S. E.}

The Expedition to the Olympic Mountains, authorized by the Executive Committee of the Field Columbian Museum, left Chicago on the 16 th July, 1898, going via Seattle to Port Angeles; on the Straits of Fuca. At Port Angeles most of the outfitting was accomplished, and on the 24th July, the pack train, consisting of nine horses, carrying our camp equipage, and conducted by six men, left the town, and started on the journey into the interior of the Mountains, which loomed grand and massive before us, their rugged sides and towering peaks, many of them crowned with snow, shadowed in the clear waters of the sea that washed the shore at their feet. The first day we only traveled about ten miles, along a well-made road, that is intended eventually to reach Lakes Southerland and Crescent, the most important bodies of fresh water in this remote corner of Washington. From our camp, known as MacDonald's ranch, there was only a narrow trail running along the eastern bank of the Elwah River, which rushes and boils with a wonderful rapidity and force in its headlong march to the sea. The trail by no means keeps near to the stream, but mounts occasionally several hundred feet above it, and one, from these heights, can look down, almost perpendicularly at times, through the forest of mighty trees, and catch here and there amid the foliage, glimpses of the foam-covered, troubled waters.

Our difficulties of the march commenced at the beginning, for one of the horses, while attempting to pass a slippery spot on the trail, missed his footing, and rolled with his pack some fifty feet into the valley below. He struck on his back with a force that awoke all the echoes of the mountains, and we hastened to where he had fallen, expecting to meet only a mangled body, instead of which we found he had struggled to his feet, and was yawning mightily as if he had just awoke from a sound sleep. He had struck squarely on his back, and as he happened to be carrying the bedding, the soft blankets, etc., 
had saved him probably from instant death. As it was, he escaped with the loss of one eye, which had struck on a root as he reached the ground. We camped that evening at a deserted ranch, owned by a Swede by the name of Johnson, who, suffering from an attack of gold fever, had gone to the Klondike. The camp was on the bank of the river, about ten feet higher than the water, and a short distance above a cañon. This was about one hundred feet wide, with perpendicular walls, between which the river tore along with irresistible strength. In the spring, during floods, huge trees, perhaps thirty feet in circumference, are hurled through this gorge with the power of a catapult, and in a crevasse of the rocks one old forest monarch has been wedged by the power of the furious river, twenty feet above its ordinary level. We remained in this camp a week, and ob. tained a large number of desirable mammals.

Our route from here was across the river, and at the end of the week the water had fallen sufficiently to permit our horses to cross at a ford a short distance above our present position. Two miles above, on the western bank, we camped near the mouth of a brawling stream that tore down the valley, coming from far in the mountains, and was lost in the rushing Elwah. From this point there was no trail, and for the next ten days the men were busy cutting a path through the forest on the mountain sides, until they reached a height where the trees became fewer, and then gradually disappeared at timber line. We were trying to reach the country where the elk were accustomed to pass the summer, just beneath the everlasting snow of the higher range. The forest was primeval, and the individual trees gigantic, many mounting upward for one hundred and fifty feet, perhaps more, without a branch, a massive trunk rising in the air straight as a needle. These magnificent cedars are characteristic of the northwestern forests, and are very impressive from their enormous size. The journey up this trail was a very rough one,hard on men and horses. Two of these the first day indulged in some somersaults, which, fortunately, did no damage to them or their loads, and we eventually arrived at a small pond named Happy Lake, a view of which is here given, and camped. The trail, however, had been so steep, exactly like crawling up one side of a peaked roof, that the loads on the horses had to be materially reduced, as it was impossible for them to climb, heavily loaded as they were, and it was several days before all our impedimenta was gathered into camp. We were now at a height of something between five and six thousand feet; my aneroid gave fifty-three 
hundred; but I think it underrated the elevation, as I had noticed it was not so accurate when tested with known heights, as it had originally been. Our first camp was near the borders of Happy Lake, but the mosquitoes were so numerous and extra ferocious that we were obliged next morning to move to a locality about three quarters of a mile away, where a level place sufficiently large was found, on which to pitch our tents. This was not by any means an unusual occurrence in our journeying through these mountains. They were so exceedingly steep, and their sides so broken up by ravines, landslides, and every kind of obstruction inimical to level ground and peaceful progress, that places suitable as sites for tents were not easy to find. The accompanying views give a very good idea of the appearance of Happy Lake, and of the first location of our camp in the vicinity. Some elk signs had been seen in our wandering about the neighboring "hog-backs" and peaks, and in one spot was plainly visible, where four of the animals, affrighted at some object or sound, had dashed down the almost perpendicular side of the mountain into the depths below. So steep was this descent that none of us would have cared to attempt it, but fear may at times carry animals in safety through perils, which if dared in cold blood, would have probably caused their destruction.

We were nearly three weeks at this camp, during which time we were engaged cutting a trail farther into the mountains, and hunting and exploring their valleys and summits. Flowers of all kinds and hues were blooming in profusion about us, and certain tracts were a mass of one solid brilliant color, as though laid out by the hand of some skillful gardener. Our tents were pitched on the edge of a ravine, at the bottom of which flowed the waters of Happy Lake on their way to the sea, and across this and over the ridge of the Storm King range, rising above Lake Crescent, we could see on a clear day the waters of Fuca Straits, with the ships sailing from or to the Pacific, and the island of Vancouver beyond, with its surface broken by hills and high mountain ranges. South of the camp rose a lofty "hog-back," from whose crest could be obtained a fine view to the north and south. This ridge terminated in a steep peak towards the west, from which one looked down into the yawning depths beneath.

Nothing is gradual in these mountains, extremes are always present. Everything seems to stand on one end like the trees, and the soil is only kept from tumbling into the valleys by the rocks, which seem every moment about to lose their hold and dash in to the abysses below them. Looking south from this "hog-back," across the intervening 
valleys, through one of which flowed the waters of the creek, known as Boulder, and which emptied into the Elwah, near our second camp on that stream, could be seen the north wall of the central snow range, rising perpendicularly from the valley, and inaccessible from that side by even a goat. Its summit was broken by many a yawning chasm of unknown depths, and on whose brink no foot of man had ever trod, with craters of extinct volcanoes opening their great mouths to the sky and disclosing their smooth interior walls going sheer down for hundreds of feet until hidden in the depths, or disappearing in the snowdrifts that filled the interior two-thirds to the crater's lip. In one of the strolls around camp Mr. Akeley, who took all the views that illustrate this paper, found a squirrel asleep on a $\log$, and after getting the proper focus, he awoke the little fellow, who, disgusted at being disturbed in his nap, began to swear at his tormentor in the most vociferous and reprehensible manner. While in this excited condition his portrait was taken, as shown in the accompanying view.

The trees at this altitude were black spruce, hemlock and firs, giving a sombre and lonely appearance to the landscape. The spruce grew in clumps of six or eight, ranged generally in a circle, their branches sweeping the ground, and affording in their midst a good shelter from the wind and rain, but they were good for very little else. Although we hunted continually, no elk were seen while we remained at this camp, and deer, the true black-tail, (O. hemionus. Rafin.), the only species found in these mountains, were very scarce, and we only succeeded in obtaining a doe and a fawn. But our collection increased considerably, although the variety was not great. I do not think I was ever before in a country that was apparently so devoid of animal life. One might walk for days and see nothing save a squirrel, chipmunk, or blue jay, and only occasionally be challenged from the higher peaks by some watchful marmot, whose shrill whistle awoke the echoes around, as he expressed his disgust at the intrusion of an inquisitive and troublesome biped. Not far from our tents, measured by distance, but exceedingly far off when the climb back was considered, for it was situated deep down in a valley by a running stream, was a colony of the unique Sewellel, a species that seems to have lingered beyond its time on the earth, and known to the people as mountain beaver or Farmers, though seldom had any one seen the animal. An account of its queer appearance and strange habits is given in the proper place in the catalogue of mammals included in this paper.

By the newly cut trail along the "hog-back" and through the forest 
which covered portions of the route, we made our way to our next camp, farther in the mountains and nearer to the forbidding north wall of the main snow range. We overlooked a small lake lying deep down in a hollow, known to us as Boulder Lake, and whose waters, plunging down a precipitous cliff at the outlet, formed the creek that terminated at the Elwah River. The accompanying view gives a good idea of the wild and savage scenery at this place. Most of the cliffs were covered with loose stones and sand, and were much steeper than they appear in the picture; in fact, in all but a few places, being impossible to climb. The summits on the south of this lake were so broken by jagged ridges, impassible ravines, snowfields of uncertain depths and yawning chasms, that progress in any direction. was out of the question. A view taken from the west of the lake, looking towards the southeast, gives a fair idea of this promising land, the rocky bluff on the left side being the "pathway" that had to be descended in order to cross the "hog-back" seen in the lower part of the view. The mountains in the distance are a portion of the central snow range.

It was soon ascertained that it would be impossible to go farther south, either with horses or men, and as elk seemed to be exceedingly scarce in the locality, I desired to cross, if possible, the intervening range to the west and strike the head-waters of the Solduck, a river of similar character to the Elwah, but smaller, and which emptied into the Pacific Ocean. Mr. Akeley and two men made a day's trip to see what could be done, and reached the second ridge to the westward. They found five lakes, one of which they named Elliot Lake. It lies well towards the snow range, deep down amid the mountains, and is square in shape, quite different in this respect from all the other bodies of water, which are either oval or round. Elliot Lake is, perhaps, about one-third of a mile in length, of great depth apparently, and probably occupies a small crater of some extinct volcano. From its isolated and almost unapproachable position it will probably never become a summer resort for tourists, nor is it likely that many persons will ever gaze upon its quiet waters. The "hog-backs" in many places were so sharp that it was necessary to place one foot on each side of the ridge and so shuffle along, while the perpendicular sides shot down below many hundred feet, and the slightest stumble, or rolling stones or sand might cause the loss of foothold, followed by a swift descent into the depths, and consequent utter annihilation of the explorers. One more effort was made to find a passage to the west for our train, and I sent out three men, who were gone two days and a night, and who 
reported that it was impossible to go farther. We seemed to have reached the stopping-place, and that wings were the only possible means of locomotion in any direction save on our back trail.

From certain points on the ridges fine views of Mt. Olympus were obtained, and the great mountain loomed heavenward bearing its mighty glaciers and fields of snow that glistened in the sun. Rumblings were heard as if avalanches were descending; these succeeded by a crash after a few seconds' interval, and this was imagined to be some swift moving glacier on Olympus that reached the edge of a chasm, broke off and fell into the gorge, possibly the cañon of the Hoh, in a similar manner as the Muir glacier is constantly throwing off bergs with explosions like the discharges of artillery.

Farther progress being impossible, I decided to retrace our steps, descend the Elwah to a point where our first camp from Port Angeles was made, and cross by a trail that led to Lakes Southerland and Crescent, and then follow up the Solduck and cross to the headwaters of the Bogashiel River, which is stated to take its rise from one of the glaciers on Mt. Olympus. Great fires were now raging in the mountains, as no rain had fallen for six weeks, and dense smoke obscured all the view and effectually put an end to photographing. A perfectly beaten and easy trail runs along the Solduck, and horses travel it frequently, but from the Solduck to the Bogashiel is another matter. The trip to the latter river was successful, five elk having been obtained, but the animals were scarce and they were only procured after much toil and privation. The country, when the vicinity of the snow range is reached, is so rough and broken that it is next to impossible for a man to travel over it, and to take horses is out of the question, and ours were left for a month shut in a grassy place. Everything must be carried on one's back, and every year the elk that remain are retiring farther into the recesses of the mountains. The rainy season had also set in, and out of thirty days it poured more or less in torrents for twenty-eight. On this elk trip nocollection of small mammals was made. A fine series of fish was procured from the two lakes embracing every species known to inhabit these waters, and some new ones. A list of these will be published by my chief assistant, Dr. S. E. Meek. The trout in Lake Crescent grow to an enormous size, and one specimen was taken that weighed thirteen pounds. Altogether between five andsix hundred specimens of mammals were obtained, with few exceptions embracing all the species known to inhabit the region, besides the fish above mentioned, and sundry reptiles and insects. 
In the preparation of the following list I desire to express my thanks to Prof. J. A. Allen of the New York American Museum of Natural History for unrestricted access to the fine collection under his charge, and to Dr. C. H. Merriam for loan of sundry topotypes of his species for comparison.

\section{ORDER RODENTIA.}

\section{FAMILY SCIURID瓜.}

\section{Sciurus douglasi.}

Sciurus douglasi. Bach, Proc. Zool. Soc, , vol. vi, I838, p. 99.

This is the only squirrel of this genus found in the mountains. It is in evidence wherever one goes, but is not so plentiful in the higher ranges. A good deal of variation is seen in the color of individuals, such as the depth of the hues on the under parts, which runs from a pale yellow to a deep rich orange. This may be caused to some extent by the state of moult, for apparently individuals do not all change their pelage at the same time, and also, age and sex have considerable influence upon the appearance of the coat. The color of the back and upper parts varies in the depth of the grizzled rufous or rusty, and the tails are so differently colored at times that it is a cause of doubt whether the individuals to whom they belonged are really all of the same species. Only one specimen in the series shows any white in the axillæ. The black mark along the sides also varies both in extent and intensity.

Fifty examples: McDonald's Ranch, Elwah River, I ; Johnson's Ranch, Elwah River, 8; Boulder Creek, 33; Happy Lake, 6 ; Boulder Lake, 2.

\section{SUBGENUS EUTAMIAS.}

\section{Tamias townsendi.}

Tamias townsendi. Bach, Jour. Phil. Acad. Nat. Scien., vol. viii., pt. I, I839, p. 68 .

This pretty chipmunk was met with generally throughout our journey, and was especially plentiful among the lower ranges of the mountains, but appeared in lessernumbers at timber line, and was rarely found near the central snow range, being replaced by the succeeding species. I noticed a decided difference in the call of the individuals that dwelt at different altitudes. Those of the valleys and lower hills uttered a querulous chirp, while those near and at timber line called attention to themselves by a short, sharp, hoarse bark. I never heard on the top of the mountains 
the querulous chirp uttered everywhere by the species at lower levels. Excepting this call, there was nothing in either their habits or appearance that was different between individuals from separate localities.

This animal did not enter a trap readily, and many we procured were shot.

Forty-four examples: McDonald's Ranch, Elwah River, I; Boulder Creek, I3; Happy Lake, 38; Boulder Lake, 2.

\section{Tamias caurinus.}

Tamias caurinus. Merr. Proc. Acad. Nat. Scien., Phil., I898, p. 352 .

This species is only found among the higher ranges of the mountains. We first met with it at Happy Lake, about 5, 000 feet of altitude, but in the Solduck valley I think it goes somewhat lower. It could not be called abundant anywhere and was much less often met with than was the preceding species lower down the mountains. The adults were shy and very difficult to trap, and to obtain them we were obliged to rely mainly on the gun, but the young were trapped easily. While resembling $T$. amanus, Allen, from California, it also is very close to $T$. affinus, Allen, from British Columbia, differing, however in the darker color of the head, wider central black stripes, and duller intermediate stripes on the back. The rump also is not a clear grey.

Fifty-three specimens: Happy Lake, 5o; Boulder, 3.

\section{Arctomys olympus.}

Arctomys olympus. Merr. Proc. Acad. Nat. Scien. Phil., I 898, p. $35^{2}$.

This marmot is found in the higher altitudes of the Olympics, and was first seen by us between four and five thousand feet above the sea. It is especially plentiful on Mount Angeles, and is met with in small colonies throughout the range traversed by us. As soon as any intruder is sighted, the loud, shrill whistle of some sentinel perched upon a commanding rock is heard startling the lively echoes, and, if in summer, his yellow body discloses his whereabouts, as he sits upon his haunches, watching the unwelcome visitor. The sound this species utters is exceedingly shrill and piercing, and gives to it the common name of "whistler," and it often misleads one wandering among the cliffs, who imagines that some companion is calling to him, rather than that so powerful a whistle should be emitted by any small mammal. This species is small only by comparison, but is large for a marmot, some specimens weighing as much 
as twenty-five pounds. In summer the color is ochraceous yellow, varying in shades among individuals. In winter this changes to a dark, bluish-grey. The color of the legs and feet varies among individuals, from an almost pure black, with some grey hairs intermingled, through the different shades of chestnut to a rich brown. The animals appear to shed their coat very irregularly, and specimens are met with on the same day representing very different stages of pelage. Some are all ochraceous, others are half ochraceous, (usually the upper part of the body), and half grey, while again others are in various stages of dilapidation, and present a ragged coat of grey and yellow, diversified with so many hues and patches, that it may fairly be supposed to represent the celebrated coat of ancient times stated to have been worn by Joseph. It is difficult to procure an example properly arrayed in a dress of one color. This species makes its burrows among the rocks, and forms regular paths from the entrance of one burrow to that of the others, so if an individual is surprised away from home, he has no difficulty in taking refuge in an abode of some relative. It is a very powerful animal, and if caught in a trap can walk away easily on three legs, carrying the trap with it. If shot in the vicinity of the burrow, this marmot possesses all the skill and agility exhibited by the prairie dog in reaching the entrance and disappearing underground. And even if, when attached to a trap, they find themselves just beyond the opening, and unable to drag their load in with them, so firmly can they hold to the earth with their forelegs, that it is only with the greatest difficulty that they can be drawn out.

Eight specimens: Happy Lake, 7; Boulder Lake, I.

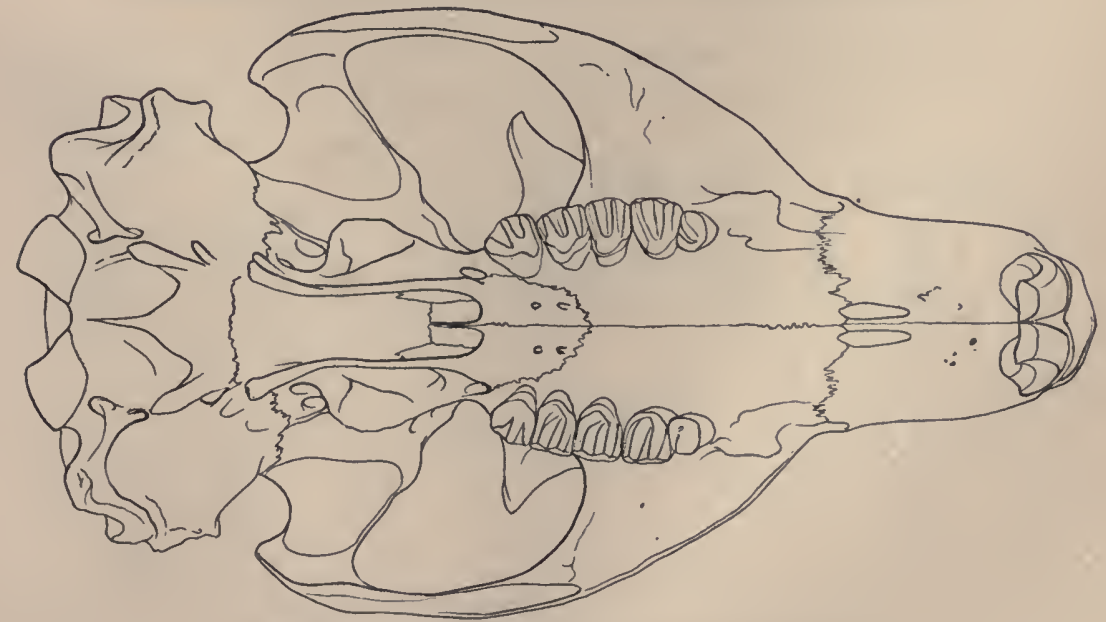

This figure represents lower view of the skull, natural size. 
5. Sciuropterus alpinus olympicus.

Sciurus alpinus olympicus. Elliot, Pub. Field Mus., Feb. I, I899, p. 225 .

This splendid species was obtained only on top of the mountains, in the vicinity of Happy and Boulder Lakes, the farthest points at which we made a regular camp on the Elwah River side of the snow range. I have reason to believe it is found much lower down on the Solduck trail. We never saw the squirrel in the trees, and it must be strictly nocturnal in its habits. The four specimens procured were all taken in.traps, some of them placed quite a distance from trees, which showed that the animals must do considerable traveling over the ground. Not having seen any flying squirrels, nor any evidence of their existence, it was both a great surprise as well as pleasure to find an individual one morning in a trap placed upon the top of a large rock. Its deep, rich coloriug, verging to a jet black on the wing membranes, at once attracted my attention, and together with its great size caused me to regard it as different from anything I had previously seen. The species appears to go in pairs, for in each locality that we obtained specimens those of each sex were procured. It does not seem to be plentiful, else it is probable we would have taken more examples; but although at times we had as many as one hundred and fifty traps set, we only took four of the species. In my description I have pointed out where this form differs from $S$. a. 'fuliginosus as described. It would seem, while it is evidently much darker in its coloration, it is also much larger; in fact, the largest of the flying squirrels yet discovered on this continent.

The measurements of the four specimens are as follows:

\begin{tabular}{|c|c|c|c|c|c|c|}
\hline No. & Sex $q$ & Total Length. & Tail. & Hind Leg. & Ear. & $\begin{array}{l}\text { Flying Membrane } \\
\text { Across Shoulders. }\end{array}$ \\
\hline $\begin{array}{r}\text { Type } 418 . \\
408 . \\
395 . \\
488 .\end{array}$ & $\begin{array}{l}\cdots \\
\text { o } \\
q \\
\text { ô }\end{array}$ & $\begin{array}{l}\text { 346. mm. } \\
336 . " \text { " } \\
329 . " \\
328 . "\end{array}$ & $\begin{array}{l}164 . \\
166 . \\
159 . \\
160 .\end{array}$ & $\begin{array}{l}38 . \\
37 . \\
37 . \\
35 .\end{array}$ & $\begin{array}{l}\cdots \\
18 . \\
20 . \\
20 .\end{array}$ & $\begin{array}{l}200 . \\
230 . \\
216 . \\
228 .\end{array}$ \\
\hline
\end{tabular}




$$
\text { 2. TII! }
$$

UNIVERSITY OF ILLINOIS. 


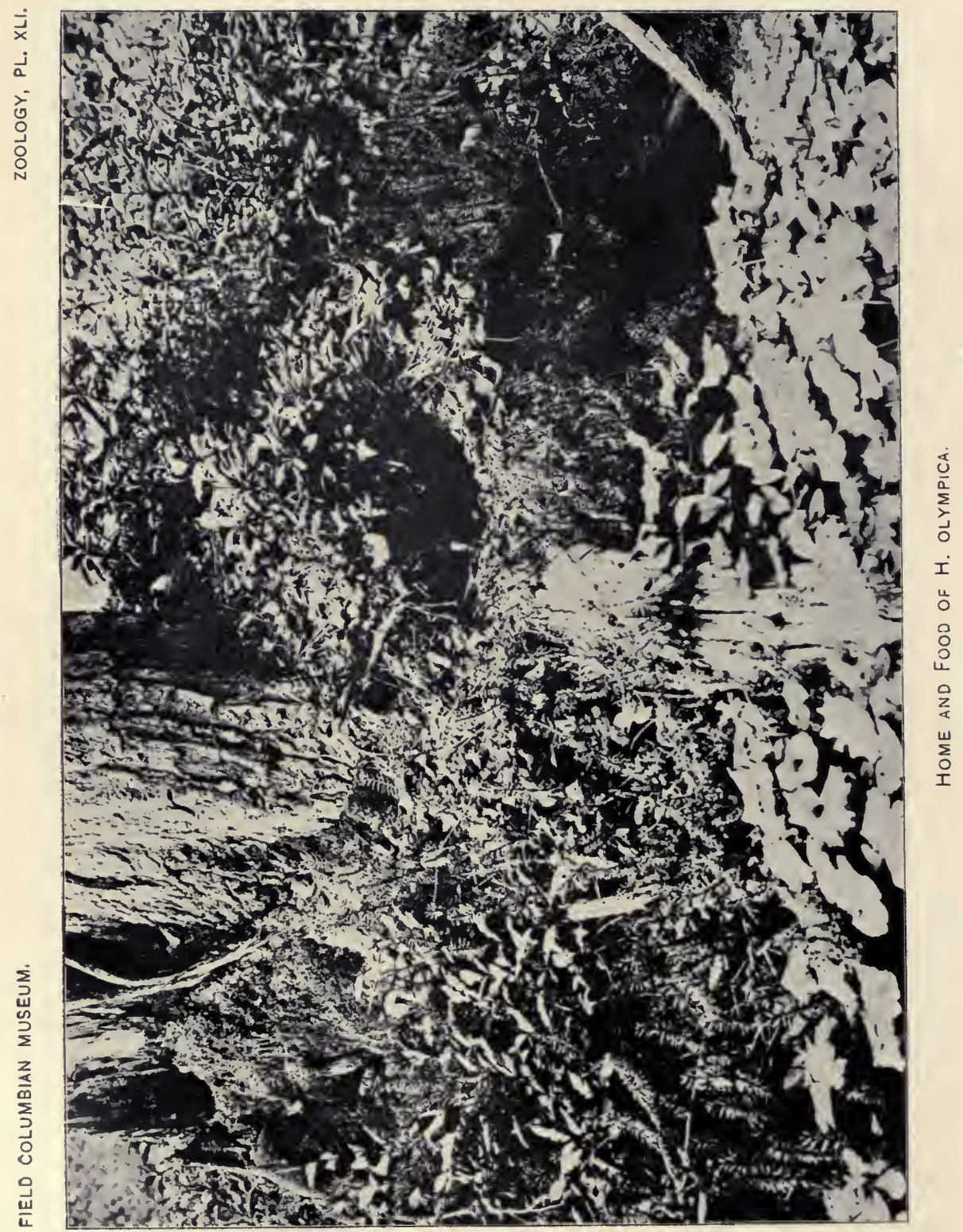




\section{FAMILY HAPLODONTIA.}

6. Haplodontia olympica.

Aplodontia olympica, Merr. Proc. Biol. Soc., Wash., Vol. XIII., I 899, p. 20.

Dr. Merriam has lately described a Sewellel from Lake Quinault, in Gehalis County, Washington, lying among the foot hills of the Olympics, and having kindly sent me a topotype for comparison, I find it to be the same as my examples. I obtained. thirteen specimens, adults and young, the first two at Johnson's ranch, on the Elwah River, the remainder on the tops of the mountains, at Happy and Boulder Lakes. I had supposed that these represented typical $H$. rufa; but not having, unfortunately, any specimens of that species, but only the one from California, $H$. major Merr. $=H$. leporina var californica, Peters* to compare with, I was unable to arrive at a definite conclusion. Dr. Merriam shows in his paper that the skull of the Olympic Sewellel differs in various ways, sufficiently to separate it from its allies. In my specimens the nose and space around it are black. The white spot at the base of the ear, like the one on the breast, can in no way be considered a specific character, but is an individual peculiarity, as some of my specimens have these conspicuously shown, while others have no trace of either.

This peculiar little rodent is known to the settlers as the Gehalis, Mountain Beaver, and Farmer, the last name being the one most commonly employed. Few have seen it, as it has secretive habits, and the fact that it rarely moves about much during the days, gives but few opportunities for observing its ways and mode of life. It keeps to wet and swampy places, and near to small streams and mountain brooks, and makes its burrows in the banks. Sometimes, however, these are dug in the ground, in the midst of tall grasses growing densely together, and paths are trodden down connecting the various entrances to their underground homes. The muscle of the neck and jaws are very large and powerful, and they can bite with great force. The hinder part of the body is comparatively weak, and the hind feet are much more slender than the hands. The ribs also are slight and rather delicate, and the skeleton has the appearance of being rather too feeble to carry the

* Monstab. K. P. Akad. Wissench. Zu. Berlin, 1864, p. I79. 
large skull. While in the bushes or grass the movements of this animal appear to be exceedingly quick, as it would immediately disappear from view, yet those that $I$ have seen in the open did not move with unusual rapidity, the heavy body and exceedingly short legs being apparently decidedly opposed to any celerity of action. The most peculiar habit to which they are addicted, and which gives them their commonly accepted name of "Farmer," is that of making "hay." They usually dig their burrows in the vicinity of a water plant, apparently a kind of low-growing lily, and this they cut down in quantities and carry it near the mouths of their burrows, and spreading it out leave it to be dried by the sun, and when sufficiently cured it is drawn into the holes to serve either for food or bedding, perhaps both. The photograph gives a good idea of the place the animals select to live in, and of the plant which they use for making hay. This was near our camp, in the vicinity of Happy Lake, and was the resort of quite a colony of "Farmers," most of whom returned to the East with me.

This animal has a most peculiar hand, admirably adapted for grasping. Near to an opposable thumb is a prominent, somewhat lengthened basal tubercle, and any object placed between this and the thumb is held very firmly. The enlarged photograph of the hand, taken from life, shows this and the other tubercles very plainly.

It would seem as though too many forms of this genus had been described; but without the same material to judge by, it is never wise to cast doubt upon another's decision who has been more favorably situated and better able thereby to arrive at a more correct conclusion. At the best, however, it can only be considered that the work of all those at present engaged on North American mammals is but tentative, and we must wait for the future monographer who, with all the material now available, shall add to it a very large number of additional specimens to determine the proper status of many forms now regarded as distinct.

Twelve examples: Johnson's Ranch, 2; Happy Lake, 9; Boulder Lake, I; I skeleton, Happy Lake. 


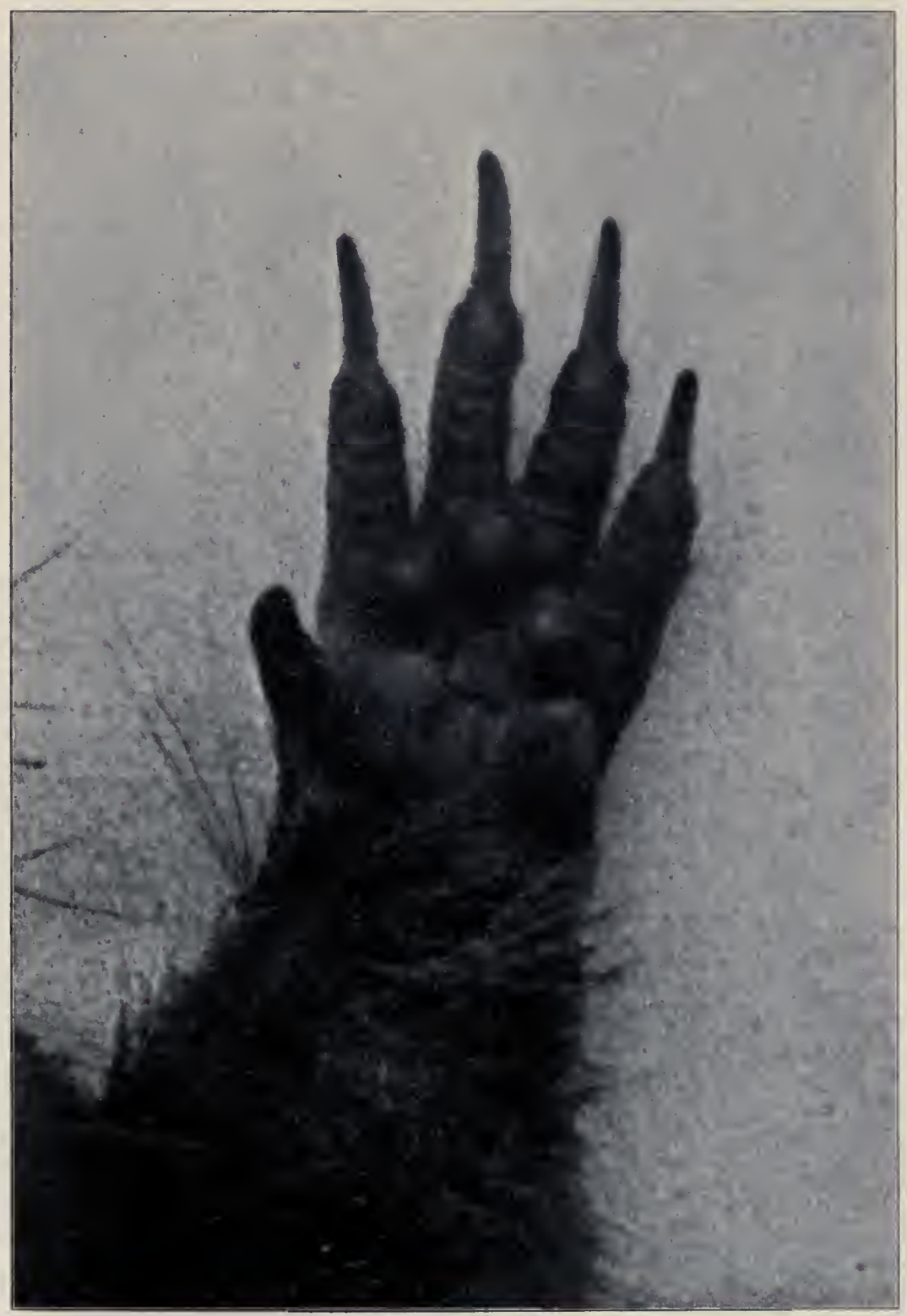

HaNd of HaPlodontia OLYMPICA. 
LIBRARY

OF THE

UNIVERSITY of ILLINOIS,

. 

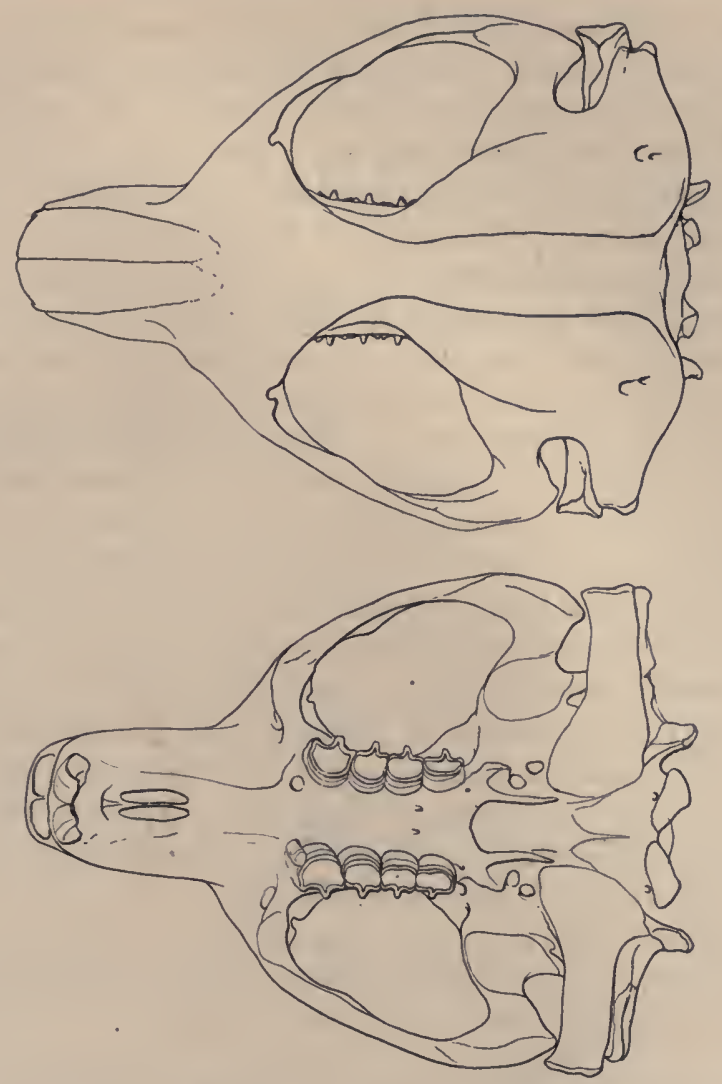

The cuts exhibit the upper and under surface of the skull, natural size

FAM. MURIDA.

\section{Peromyscus akeleyi.}

Peromyscus akeleyi. Elliot, Pub. Field Colum. Mus., I899, Feb. I, p. 226.

This is the prevalent species of mouse throughout the Olympic Range, or at least that portion explored by my party. It was very abundant, and we were always pretty certain to find some individuals in the traps every morning. The very old animals were difficult to obtain, consequently the rufous colored specimens like that described as the type were rare, the majority being the darker colored examples with an almost black dorsal area. Ears are quite large and prominent and the tails, especially of 
those procured on top of the mountains, conspicuously long. A very fine series was obtained showing all stages and variations of pelage from the young to the old adults. In the preliminary description of this species (1. c.) I compared it with $P$. t. boylii, but on showing my examples to Mr. G. S. Miller, he suggested that $P$. canadensis might prove to be a nearer relative, and after making a comparison with this species I am inclined to believe that Mr. Miller is correct in his view. $P$. akeleyi is much larger than canadensis and has a longer tail, but the texture of the fur is very similar, and the color more nearly resembles that of canadensis than it does that of boylii. The two forms, however, are very distinct. The skull, compared with that of canadensis, is longer, wider at the occipital region, frontals less constricted, nasals broader and not rounder at the anterior end, auditory bullæ barely equal in size; lower edge of foramen magnum to pos. terior edge of palate of greater length, and palate slightly shorter. Total length from occiput to anterior end of nasals, $26 \mathrm{~mm}$; nasals, 8.5; anterior edge of palate to alveolus of middle incisor (inside), 7; length of palate, 4; posterior edge of palate to lower edge of foramen magnum, 8 ; tooth row, 4 ; zygomatic width, 8 .

I have pleasure in bestowing upon this species the name of my assistant in the field, Mr. C. E. Akeley.

One hundred and seventy-nine examples: McDonald's Ranch, Elwah River, 2; Johnson's Ranch, Elwah River, 5I; Boulder Creek, 49; Happy Lake, 45; Boulder Lake, 32.

\section{Neotoma occidentalis.}

Neotoma occidentalis. Baird, Proc. Acad. Nat. Scien., Phil., I 855 , vol. vii., p. 335 .

This was the only species of wood rat seen by us. It was in no place abundant, single families occupying certain localities, and when these were captured there was no use trapping for them any longer in that vicinity. The supply appeared to have become exhausted. This animal is the typical $N$. occidentalis Baird, and is readily recognized by its very dark, almost black, pelage, especially along the dorsal area. The young also are a very dark plumbeous, almost black. The specimens from British Columbia, especially those from Ducks, are of quite a different coloration, being much lighter, inclining to a grey. A series of the two forms placed side by side exhibits the difference in color conspicuously. I am inclined to regard this animal from Ducks 
as subspecifically distinct, and would suggest the name, *Neo- toma cinerea columbiana for it.

Twenty-three specimens in all were captured, but few of them were old individuals, the greater portion being young or young adults. This species is apparently the darkest in color of the bushy-tailed rats.

Twenty-three examples: Campbell's Ranch, Elwah River, I; Boulder Creek, 7 ; Johnson's Ranch, Elwah River, I ; Happy Lake, I4.

\section{Phenacomys olympicus.}

Phenacomys olympicus. Elliot, Pub. Field Col. Mus., Feb. I, r 899, p. 225 .

This distinct species was quite scarce, and during all our stay in the Olympics we only obtained six specimens. It seems to be a dweller of the high ranges, as we first met with it at Happy Lake just below the timber line, and saw no trace of it anywhere at lower levels. It is quite a different looking animal from $P$. orophilus, the species I compared it with, being darker and inclined to a more reddish hue. The ears are quite prominent, as is usually the case with members of this genus, stand well out of the fur, and are large for the size of the animal. The tail varies slightly in length among individuals, the average of the six examples possessed being $28 \mathrm{~mm}$., a little longer than that of the type. The longest tail is $3 \mathrm{I} \mathrm{mm}$. and the shortest $28 \mathrm{~mm}$.

Six specimens: Happy Lake, 5 ; Boulder Lake, I.

The figures show the inferior surface of the skulls of the present species and $P$. orophilus, natural size, and also the upper tooth row of each, something between six and seven times greater than natural size.

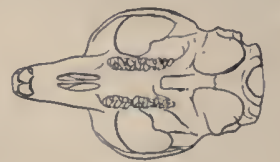

P. OLYMPICUS. (Nat. size.)

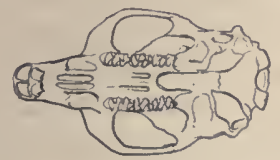

P. OROPHILUS.

(Nat. size.)

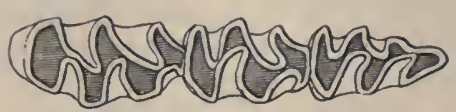

P. OLYMPICUS.

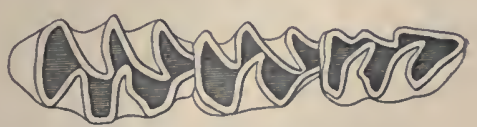

P. OROPHILUS.

* neotoma c. columbiana.

Type No. 4910, Field Columbian Museum. Ducks, British Columbia. 1, Aug. 1889. Nose and space between eyes light mouse grey. Top of head and back dark grey. Sides of face and flanks, 
Io. Evotomys nivarius.

Evotomys nivarius. Bailey, Proc. Biol. Soc., Wash., I897, p. I 36 .

This is apparently an Alpine species and was obtained in the same localities in which Phenacomys olympicus was procured. Although I have not seen any example of $E$. nivarius, the description of that species given by Mr. Bailey (1. c.) appears to agree so well with the general aspect of my specimens, that I have little hesitation in considering them to be the same.* The measurements of my examples, however, are somewhat less than those given for $E$. nivarius, and the largest out of twenty-two individuals has the following dimensions: Total length, I $37 \mathrm{~mm}$; tail, 40; hind leg, I6; ear, 8 . In the places where this mouse was taken, the ground everywhere was studded with small holes, apparently the entrances to underground galleries, but, with only here and there an exception, these were only a few inches in depth. Now, whether this species has a very changeable mind and abandons one spot after another after digging a few inches, or makes these shallow excavations in search of the roots of certain grasses, or merely for the purpose of supplying a favorable spot on a side hill to sun itself and look around, of course I could not very well ascertain, but certain it was only a very few of the innumerable cavities had any depth, or extended beneath the surface. This species seems to dwell in colonies by itself, for in such places as just described, it was only rarely that any other kind of mouse was taken. The adults among my series have the dorsal surface strongly marked-with chestnut, in striking contrast to the grey and buff of the sides of the body. The tail is more strikingly bicolor in immature specimens than in the adults, some of which exhibit but little difference in the coloring of the upper and lower surface of this member.

Twenty-two examples: i 8, Happy Lake; 4, Boulder Lake.

shoulders and thighs, pale greyish-buff, nearly clear buff along the belly. Entire under parts and under sides of fore and hind limbs white, the blue of the base of the hairs sliowing along the sides; chest and abdomen tinged with yellow. Hands and feet white to the wrists and ankles. Tail bushy, same color as the back for about an inch and a half at the root, remainder blackish-grey; under side white. Ears with hairy fringe along outer edge, blackish; rest of ear naked. Whiskers very long, black with white tips. Measurements taken from the skin: Total length, $408 \mathrm{~mm}$.; tail to end of hair, 194; hind leg, 37. The specimen, the only one I have. is without the skull.

* Since this was written Dr. Merriam kindly forwarded to me by Mr. Bailey a topotype of E. nivarius, which proved $\mathrm{my}$ specinens to belong to that species. 
The figures exhibit the inferior surface of skull in natural size, and the upper tooth row seven times enlarged.
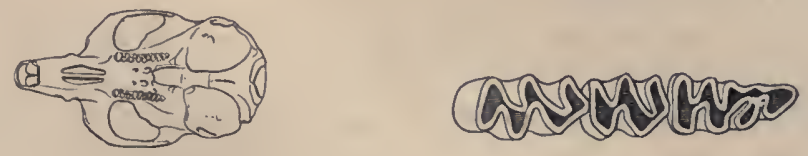

\section{SUBGENUS MICROTUS.}

II. Microtus macrurus.

Microtus macrurus. Merr. Proc. Acad. Nat. Scien., Phil., 1898, p. 353 .

This large species was only procured by me on the banks of the Elwah, and was not seen on the high mountains, so I concluded it was an inhabitant of the low lands, possibly, indeed, also a littoral form. But eight specimens in all were obtained, of which three only were adult. They merely differed, however, in size, and the young perhaps did not exhibit quite as grey a rump as did the old individuals. This color, however, is only visible in certain lights, and may probably be regarded as the sheen of the grizzled buff and brown of the upper parts. None of the tails of my specimens equal the length given by Dr. Merriam for his type, the longest being $82 \mathrm{~mm}$. This member, however, varies greatly among individuals, as my examples prove. I should judge that this is not a common species even in the localities it frequents, or else it is very careful not to occupy itself with traps, and although we endeavored to increase our series, were not able to accomplish it.

Eight specimens: Johnson's Ranch, Elwah River, 7 ; Boulder Creek, I.

The cuts show the under surface of skull, natural size, and the upper tooth row, over six times enlarged.
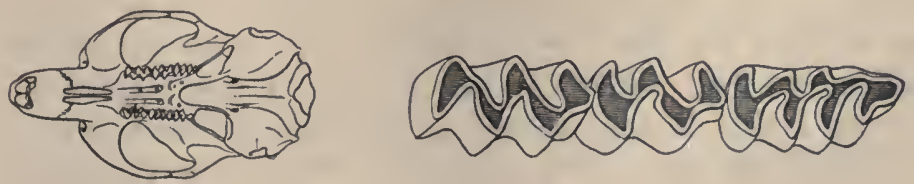


\section{SUBGENUS CHILOTUS.}

12. Microtus morosus.

Microtus morosus. Elliot, Pub. Field Col. Mus., Feb. 1, 1899, p. 227 .

This form of Microtus is generally distributed throughout the mountains, and it was obtained at all our camps when we were collecting specimens, save one, but the greatest number were procured at Happy Lake. As I mentioned in the remarks accompanying the original description (1. c.) it has some resemblance to $M$. serpens Merr., but the differences exhibited both in the color of pelage and diversity of skull make it readily recognizable. It belongs to the nanus group of Microtus. Specimens procured along the Elwah River present no differences from those obtained at timber line of the high mountains.

Nineteen specimens: Johnson's Ranch, Elwah River, 6; Happy Lake, I2; Boulder Lake, I.

The drawings exhibit the under surface of skull, natural size, and the upper tooth row enlarged over six times.
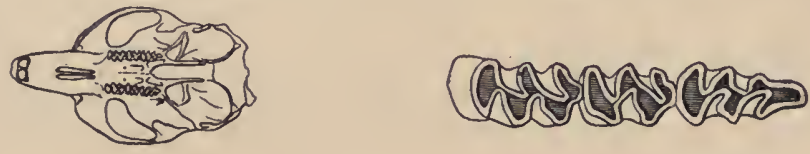

\section{SUBGENUS LAGURUS.}

\section{Microtus pumilus.}

Microtus pumilus, Elliot Pub. Field Colum. Mus., Feb. I, I899, p. 226.

It was at the camp, in the vicinity of Happy Lake, that this species was met with, and we found it nowhere else, though undoubtedly it ranges over the mountains at, or above, timber line. Only three specimens, none fully adult, were obtained among the large number of the Muridæ procured throughout our journey, and it is fair to suppose it is rather rare, at all events in the localities we visited. It is very small, almost the very least of the species of microtus yet discovered. When the first individual was caught, I was impressed with the idea that it represented a new species, and every effort was made to procure a series, but two more examples were all we succeeded in securing. The fur is very soft, and rather 
long for the size of the animal, and the color varies slightly, one specimen being somewhat lighter than the others. Possibly this may be due to age.

Three examples from Happy Lake. The figures exhibit the lower surface of skull, natural size, and upper tooth row enlarged six times. The skull of the type was so badly broken that it could not be figured, and so that of topotype No. 286 has been figured in its place.
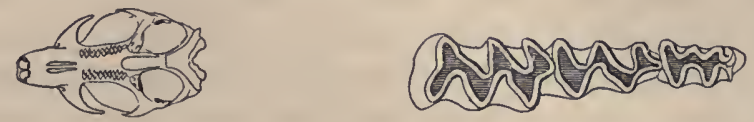

FAM. GEOMYID在.

14. Thomomys melanops.

- Thomomys melanops, Merr. Proc. Biol. Soc., Wash., I899, p. 2 I.

I was inclined to refer this gopher to $T$. mazama. Merr., but on receipt of a topotype of this species from Crater Lake, Oregon, kindly loaned me by Dr. Merriam, I find that the color of my specimens, although taken at nearly the same time of the year, is very different, and the skulls vary in many particulars. Dr. Merriam compares the skull of $T$. melanops with that of $T$. douglassi, from the north side of the Columbia River. Unfortunately, I have no specimens of $T$. douglassi. Dr. Merriam kindly sent me a topotype of $T$. melanops, and I find the same difference of coloration prevails with that species as exists between my specimens and $T$. mazama. Mine are a pale brown, while $T$. melanops is a reddish animal, with a good deal of black about the face and head. I have eight specimens all lighter than $T$. melanops. Those collected by me were taken on the east of the Divide, while Dr. Merriam's came from the Solduck River, toward its upper part, on the west side of the Divide. I forwarded one of my examples to Dr. Merriam to compare with his type, and in the opinion of himself and Mr. Vernon Bailey there was but one species, although in its lighter color and larger size, mine was distinguishable.

This gopher lives in small colonies, and is distributed generally over the mountains at or near timber line. Its presence is indicated by small mounds, similar to those thrown up by the mole; but there are no galleries beneath them, and it is 
probable that these are made in the winter, and consist of the earth thrown upon one side, while the animal is making a passage for itself beneath the snow, for the earth lies not only upon the surface of the ground, but also upon limbs and branches of trees scattered in the line of its route. At intervals along these mounds are entrances to its underground galleries, which descend directly into the earth, sometimes for a considerable depth. This animal is exceedingly, wary and cunning, and for a long time we were unable to catch it. It would not enter the traps, and when these were placed in an excavation in the gallery, it would spring them every time, or dig around them, and we despaired of ever succeeding in capturing a specimen. At length Mr. Akeley constructed a figure four trap, which would drive two spikes from above into the gallery, and when the gopher attempted to cover with earth the trigger that obstructed its path, the trap was sprung, and the animal was caught. In this way about a dozen were captured, but only two or three were ever taken from the same colony, and it seemed as if the survivors, if there were any, deserted the place, for no fresh workings would be perceived. It is a small species, the total length varying from $198 \mathrm{~mm}$. to $21 \mathrm{I} \mathrm{mm}$.

Eight specimens: Happy Lake, 4; Boulder Lake, 4.

The figures exhibit lower surface of skull (natural size), and the upper tooth row, enlarged six and a half times.
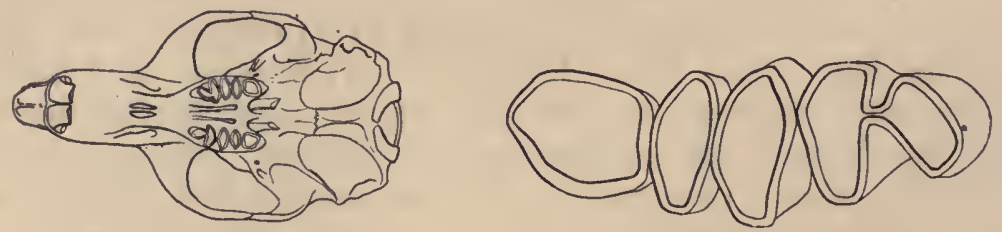

\section{FAMILY ZAPODID必.}

\section{Zapus imperator.}

Zapus imperator: Elliot, Pub. Field Colum. Mus., Feb. 1, 1899, p. 228.

This large kangaroo mouse was quite plentiful in certain localities, especially in clearings on the banks of the Elwah River, where grass seed had been sown by the owners of few ranches, some of which, however, had been deserted for the more powerful attractions of the Klondike. They were very difficult to 
catch in traps, and the greater number, composing the series we secured, were taken in butterfly nets. One of the men would go carefully through the grass holding the net before him, and when one of the little animals would disclose.his presence by leaping forward, the net holder would throw the net at him, frequently following it himself with his whole length on the ground. In this way as many as seven were taken in one afternoon. Once in the net, the mouse made no effort to escape, and was easily secured. It is the largest species of the genus, and while resembling $Z$. princeps, Allen from Colorado, is differently colored from that species, and readily distinguishable. We found this kangaroo mouse at timber line, and some specimens were taken at the farthest point we reached. One very fine adult, having been picked up dead in our camp at Boulder Lake, presumably stepped upon, or struck by a horse as it was sitting in the thick grass. It is a very attractive little creature, the immaculate white of the under parts presenting a pleasing contrast to the dark back and buff sides.

Twenty-six specimens: McDonald's Ranch, I; Johnson's Ranch (Elwah River), 6; Sieg's Ranch (Elwah River), 9; Boulder Creek, 3; Happy Lake, 5; Boulder Lake, 2.

The skull as shown below exhibits the inferior surface, and the upper tooth row enlarged six times.
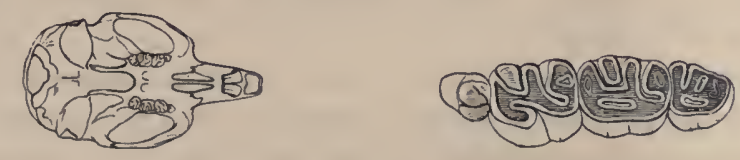

\section{FAMILY LEPORID}

16. Lepus washingtoni.

Lepus washingtoni. Baird, Proc. Acad. Nat. Scien., Phil., vol. vii., I 855, p. 333 .

This handsome hare was rather plentiful in all parts of the mountains visited by us. The settlers state that it never turns white in winter, and certainly up to the latter part of October, when there was plenty of snow around, they presented no indication of changing the hues of their pelage. Those taken were caught in cyclone traps, very few opportunities ever being afforded for the use of the shot gun. They were, perhaps, more abundant near timber line; at least we took a number of speci- 
mens at that height, but the adults seemed to be rather scarce, or it might be they declined to meddle with our traps. The adult animal is a bright reddish brown, but varies in the depths of its hue, some individuals being very much darker than others. Like all of its kind it is very agile, and it is a beautiful sight to see one bound through the.thick forest, leaping all manner of obstacles when it is once thoroughly frightened. It is readily distinguished from its relative of British Columbia $L$. a columbianus, Rhoads,

- Proc. Acad. Nat. Scien., p. 24I, I895, by the brownish-white pads under the toes. The young are colored very similar to the adult, and exhibit even more distinctly the white of the pads and especially at the ends of the toes, this being a rather conspicuous mark on the end of the hind foot above.

Twelve specimens: Johnson's Ranch, Elwah River, I; Boulder Creek, I; Happy Lake, 4; Boulder Lake, 6.

\section{ORDER UNGULATA.}

\section{FAM. CERVID瓜.}

\section{Cervus canadensis occidentalis.}

Cervus occidentalis. H. Smith, Griff. Anim. King., I827, vol. iv., pp. roI-IO3.

Cervus roosevelti. Merr. Proc. Biol. Soc., Wash., I897, vol. xi., p. 272 .

As much as we might wish that this fine animal should bear the name of the present Governor of New York, yet there can be no doubt that Smith described it more than seventy years ago (1. c.) under the name of occidentalis. There is a slight confusion where he speaks of the "tail long and dark," but as he was describ. ing the species from a drawing, this was most likely an error of the artist. The description of the horns, however, prove very conclusively that it was a wapiti, and not a black-tailed deer ( $O$. hermionus, Rafin), that he had portrayed before him, and the sketch he gives of the horn in the British Museum, pl. p. 94, with which those of the drawing were compared, and which he stated "corresponds perfectly," shows that it was a species of wapiti and nothing else that he was describing.

The antlers of this wapiti vary in size, shape, number of prongs, and the presence of "cups" and palmation of the horn, in an extraordinary degree. The typical style, or what may be called such, of well-formed antlers cannot be distinguished from 
those of the Rocky Mountain Wapiti, and this is the normal style. But there appears to be an inclination to wander from the type, so it is not uncommon to find antlers of most bizarre forms. These, however, are no indication that their bearers represent distinct species, and one would be very unwise who should attempt to create one upon such an insecure foundation. Five bulls were killed by my party, all but one, old inhabitants of the Olympics, but the antlers of no one of them bore much resem. blance to any of the others, as the photographs accompanying this paper will show. Two of them, while belonging to very large bulls, had but five points on each horn, but these differed widely in their general shape and extent of spread. The third pair were evenly branched, with a decided cup at the crown, surrounded by higher points. The brow tines, however, project almost directly forward, and were without the graceful upward curve seen in the typical style. These antlers had seventeen points. The fourth was a very extraordinary pair, being palmated from the burr for nearly the entire length of the beam. The antlers are heavy and massive, the tines being very long, and they also possessed seventeen points. I have seen palmated antlers of wapiti in the Rocky Mountains, as greatly developed as the majority of those found in the Olympics, but out of a very large number examined by myself, procured in all sections of our country inhabited by wapiti, I have never seen any at all approaching the flattened spreading beams of this pair. The bull that carried them was a very old animal, and evidently of great pugnacity, for he was covered with wounds received in battle, some of which would probably have caused his death ultimately. I give below the measurements of the antlers of these four bulls.

Failing to find any specific or subspecific character on the antlers, for any deviation from the typical style, (which is that of the Rocky Mountain Wapiti), must be considered accidental, we must turn to the animal itself, and what do we find. In nearly all seasons of the year, except winter, the color of the coat is apparently indistinguishable from that of the Rocky Mountain species, and I have seen a number of heads, killed in winter, that resembled precisely the eastern animal, being in nowise any darker. But as a rule, I believe in winter the head and neck of the Olympic Wapiti, together with the legs, reaching to groin and rump, is black, varying in intensity and in a mixture of brown, among different individuals. This peculiar coloration 
I have never seen in the eastern wapiti, and when in this pelage the Olympic animal could be always readily recoguizable. It is to be expected that all the animals inhabiting a country subjected to such an annual rainfall as is Northwest Washington, would be very dark in appearance, and this is almost universally the case, all colors being intensified, and it is not surprising that the wapiti should prove to be no exception to the rule, but assumes at certain seasons a partly black pelage. This coloring is practically the only character there is by which the wapiti of the Olympics and Rocky Mountains can be separated, and when it is absent the animals are indistinguishable from each other.

Five specimens: Headwaters Bogashiel River.

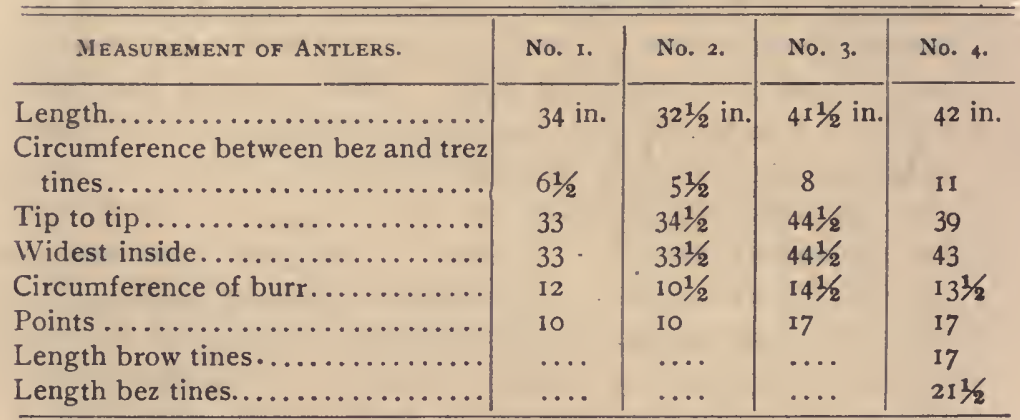

Widest palmation of last antlers, $6 \mathrm{~L} / 8$ in. (No. 4) at base of trez tines on left beam.

\section{Odocoileus herminous (Rafin).}

Cervus herminous. Rafin. Amer. Month. Mag., I, 1817, p. 436.

The true Black-tail deer was the only species represented in the mountains. Although signs were seen every day, the animals themselves did not appear to be very plentiful, considering the amount of ground we passed over, and even during the rutting season in September and October the bucks were not often seen. The summer coat of this deer is of quite a different color from any eastern species, being of a more fiery hue, and looks very handsome when seen in the thickets, which, however, is not often, for in spite of the brilliancy of its coat the animal is not readily observed, red and green being complementary colors assimilate and prevent the bright one from becoming too conspicuous. The Black-tail has all the action of the Virginian deer, and never jumps with the rubber-ball motion of the Mule deer, 



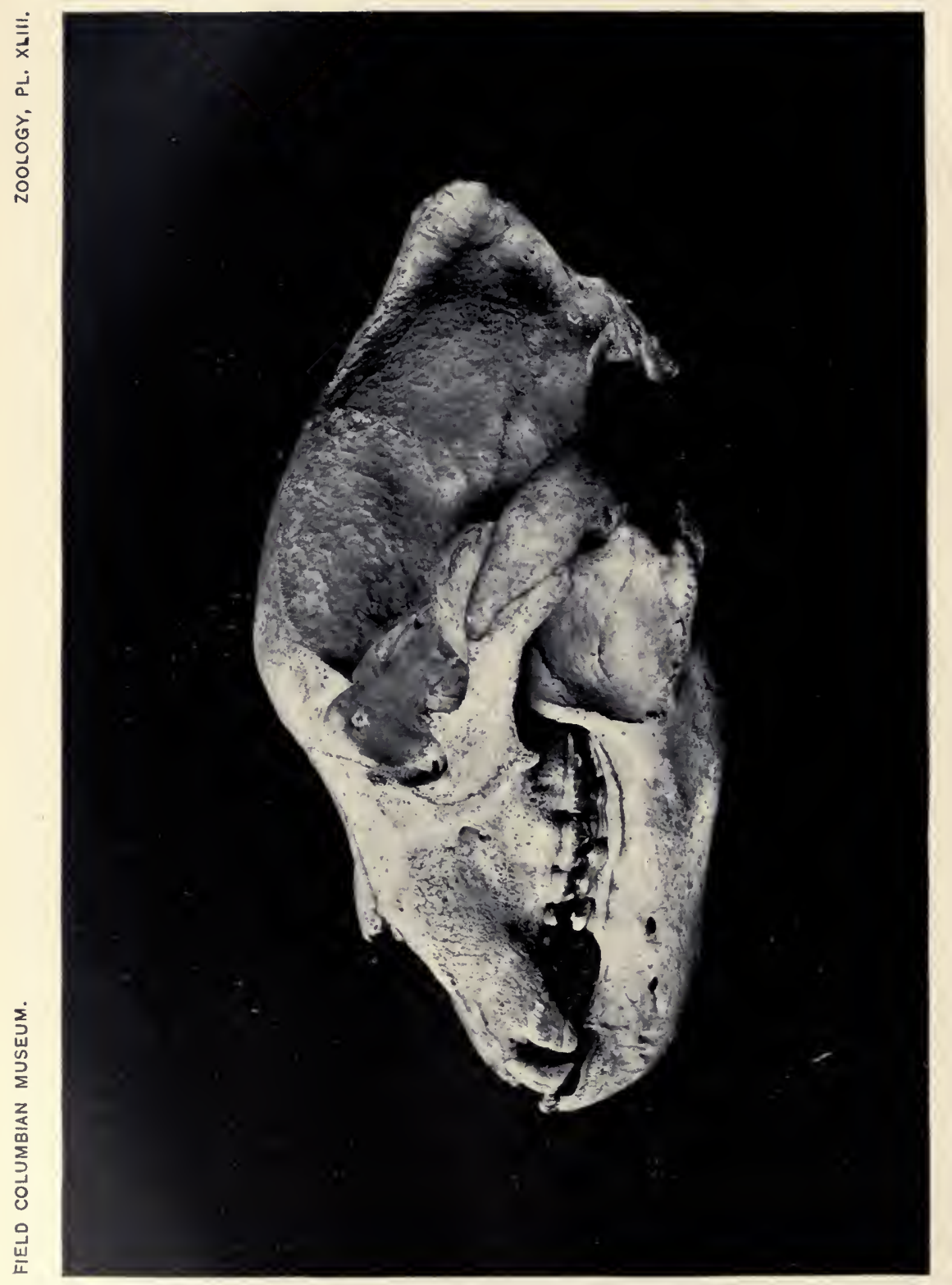

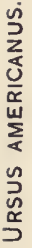


and in flight carries its tail well up. Its short legs do not permit it to stand high, and the body is chunky, and I imagine would weigh more than the average Virginia deer of the same size and age. About the settlements it is persistently hunted and its numbers have been much reduced in late years.

Two specimens: Happy Lake.

\section{ORDER CARNIVORA.}

FAM. FELID瓜.

19. Felis rufa fasciata.

Lynx fasciatus. Raf. Am. Month. Mag., vol. ii, r8r7, p. 46.

The wild cat is very numerous in the Olympics, and all that I saw were remarkable for the rich chestnut red color of their coat. Some specimens, notably the one I brought back with me, resem. ble mahogany in their coloring. It is a large animal for this form of lynx, and like all its tribe exceedingly savage.

One specimen: Lake Southerland.

\section{FAMILY URSID屃.}

20. Urus americanus.

Ursus americanus. Pall. Spicil. Zoöl. Fasc. xiv, pp. 5-7. (ז780.)

Black bear were very numerous in the mountains, and we met with them, or evidence of their presence, continually. We, however, only obtained two specimens, an old male and a cub. The animals were very shy, unusually so, and cowardly, and would go off on a full run the moment any of us was sighted. They visit the streams when the salmon are running and become very fat on the fish they catch. There are no grizzlies in the Olympics, and only occasionally, as I was informed, is a cinnamon bear seen. It would be interesting to compare a series of the black bear of these mountains with one of their eastern relatives and ascertain if there is any character for separating them. If the Louisiana and Florida bears are separable it would seem not unlikely that these animals, living in this remote corner of the United States, might also possess claims for distinctness. Mindful of the often wonderful individual variation there is seen in the skulls of pearly all species of mammals, it would not be safe to form an opinion on the specific status of the Olympic bear without having a num- 
ber of specimens available to judge from. The skull described below, may have merely peculiar characteristics pertaining to one individual and would therefore be a very unsafe guide to an opinion in the matter.

It belonged to a very old male and is somewhat unusual from the convexity of the superior outline. The frontal descends rapidly from above the orbits to the nasals, giving a very high and prominent forehead, highest behind the orbits, and then the outline descends with a moderately steep slope to the supraoccipital. A sagittal crest rises from the anterior portion of the parietal, reaching its maximum height at the supra-occipital. The face is considerably prolonged and the outline of the nasals turns upward towards the anterior end. The teeth are large and much worn, nearly smooth on the crown, the cups of the molars having practically all disappeared, and necrosis of the right mandible, near the symphysis, has caused the loss of the canine and three incisors on that side.

Length from supra-occipital to alveolus of middle incisor, inside, $325 \mathrm{~mm}$; occipito-nasal length, 285 ; width at postorbital processes, I06. These last are broad, short, rather blunt, and turn downward. Zygomatic width, I89; interorbital breadth, 73; length of nasals, 77; lower lip of foramen magnum to anterior edge of basisphenoid, 80; posterior edge of palate to alveolus of middle incisors, I37; palatal fossa, 5I; posterior edge of last upper molar to anterior edge of canine along alveolus, I00; length of last upper molar 27, width I4.

Two specimens: Lake Southerland.

\section{FAMILY MUSTELIDA.}

21. Mustela penanti pacifica.

Mustela canadensis pacifica. Rhoads' Jour. Ám. Philos. Soc., r 898 , p. 435 .

In certain parts of the mountains the fisher is not infrequently met with. Two specimens were obtained-a male and female. The first was shot out of a tree, among the branches of which he had taken refuge; the other was caught in a trap. The female is much the darker of the two. The male is much more grizzled grey on the head and neck than the ordinary eastern fisher, though I have a specimen in the Museum from Wisconsin that is also rather remarkable for the extent of this same coloring that it exhibits. This animal is exceedingly quick in all its movements, 


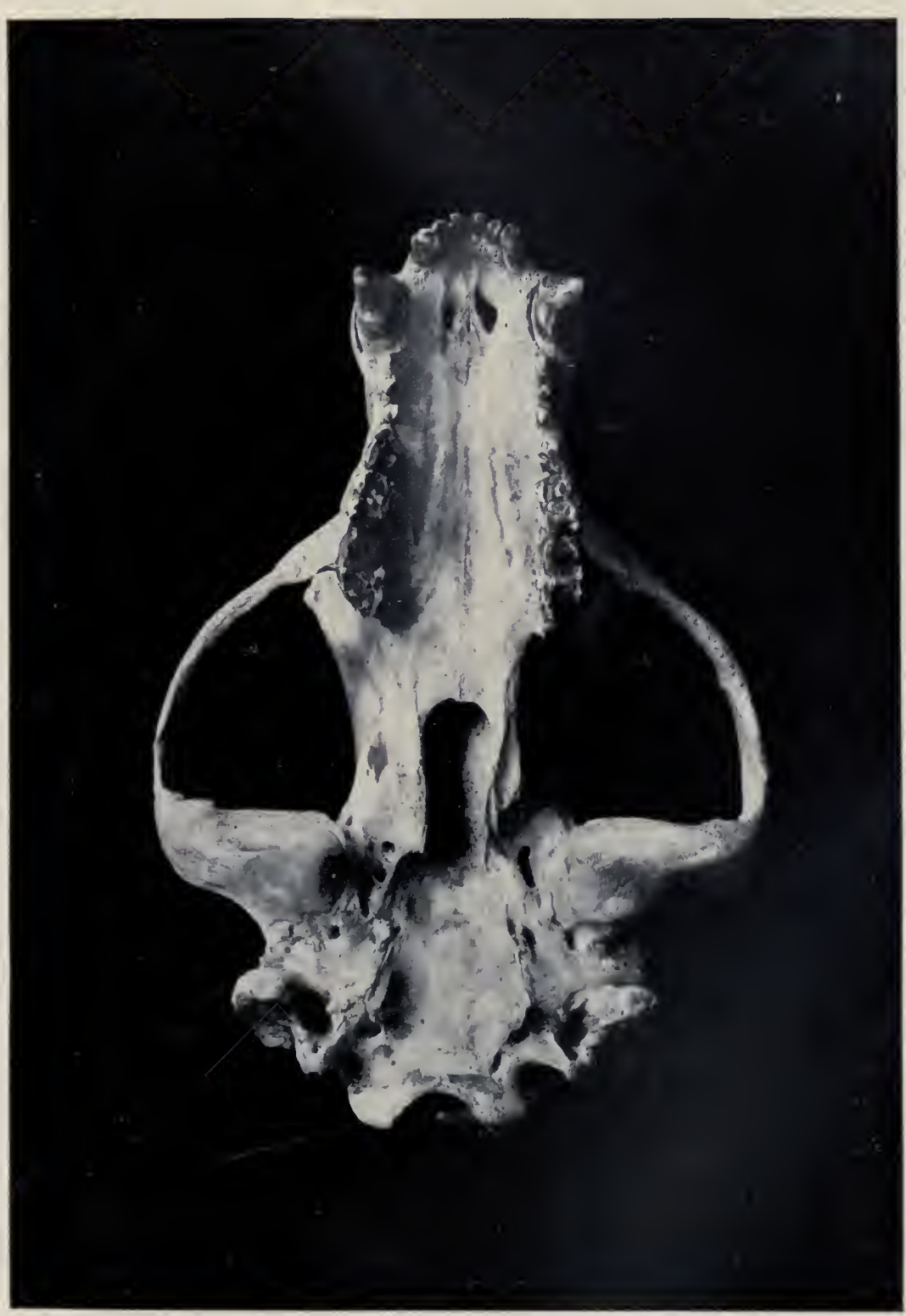

URSUS AMERICANUS. 
OF THE

UM VERSITY OF ILLINOIS. 
and a third specimen that was seen moved with such rapidity over the ground and over the trees that it was impossible to get a shot at it. In this case, however, its movements may have been hastened by a little dog that was following its track.

Mr. Rhoads (l. c.) has separated this western animal from the long known $M$. penanti of eastern North America, and given it sub-specific rank, and called it $M$. canadensis pacifica, maintaining that the true name of the eastern species was $M$. canadensis Schreb. and not penanti Erxl. Dr. Allen, however, has already shown (Bull. Am. Mus. Nat. Hist., I898, p. 46r), that Mr. Rhoads is mistaken in his view of the subject, and that the name originally given to the fisher is the one it should properly bear. Although in the recesses of the Olympics, individuals are occasionally seen and sometimes shot or trapped, yet the fisher must be regarded as a rare animal everywhere.

Its fur is long, thick and glossy, and it is a beautiful creature. Sometimes an individual is taken nearly jet black, and such a specimen is regarded as a great prize. The tail is very long and bushy and adds much to the graceful appearance of the animal. Martins are not uncommon in certain parts of the mountains, but we did not get any. The cut represents the skull of the male Fisher procured.

Two specimens: Solduck River, I; Barnes Creek, Lake Crescent, $\mathrm{I}$.

The figure exhibits the lower surface of the skull of this subspecies, natural size.

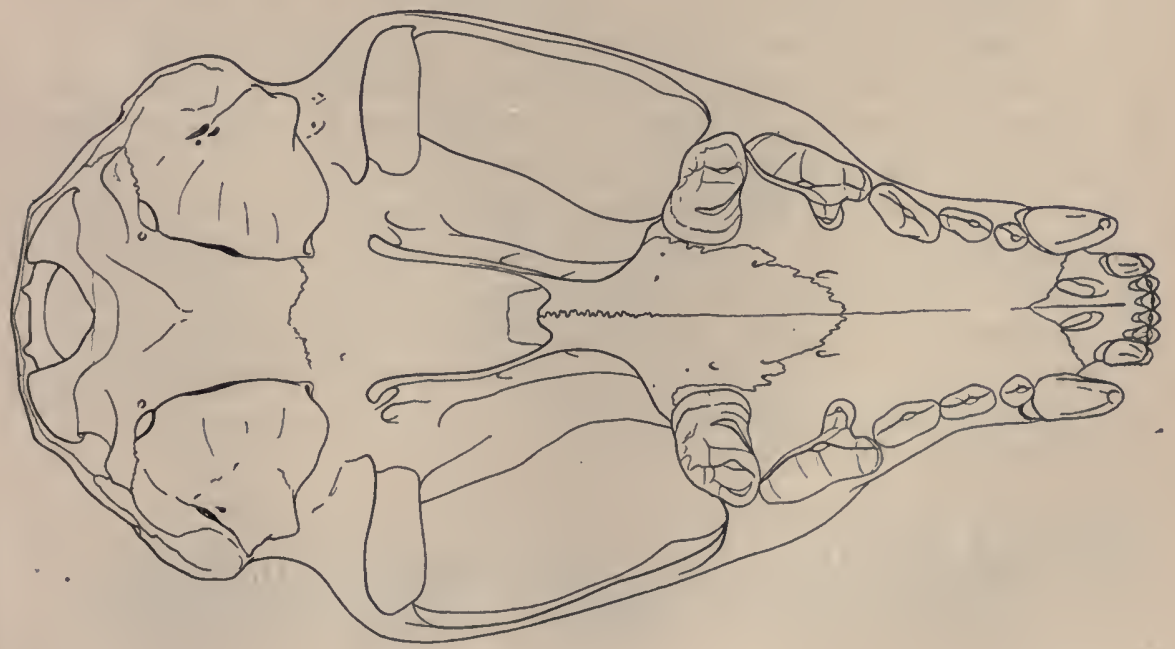


22. Putorius vison energuminus.

Putorius vison energuminos. Bangs, Bost. Soc. Nat. Hist., vol. $27, \mathrm{r} 896, \mathrm{p} .5$.

Three specimens of mink taken upon the coast at Port Angeles I refer to the sub-species described by Bangs (1. c.). It is a large animal, varying considerably in color, and some specimens have the chin and center of throat and anal region white, with straggling white hairs upon the breast. The tails have nearly the terminal half, black. One specimen has a small spot on chin, another on the breast, and the anal region, white. Specimens also vary a good deal in size.

Three examples: Barnes Creek, Lake Crescent, I; Lagune near Port Angeles, 2.

\section{Putorius washingtoni.}

Putorius washingtoni. Merr., N. Am. Faun., r896, p. 18.

Only one specimen, a female in full summer pelage, was procured, and this species did not seem to be plentiful anywhere we went. Tracks were seen along the banks of the Elwah River near the site of our first camp, but we did not succeed in trapping any there, and it was not until we reached the summit of the mountains in the vicinity of Happy Lake that the only individual we brought back was taken.

As I believe no description of this species in summer pelage has yet been published, I give the following of this specimen.

Adult female, taken 27 th August, I898, Happy Lake, Olympic Mountains, Clallam County, Washington.

Entire upper parts pale chocolate brown, this color including the flanks and the sides of the abdomen, sides and upper parts of fore and hind legs. Chin white. Under parts and lower portions of fore and hind legs and sides of neck, yellow-ochre. Tail darker than the back, inclining to reddish, with the terminal third jet black. Fore feet and wrists white. Hind feet dark brown, darker than the legs. Ears same color as back. Total length, $400 \mathrm{~mm}$; tail, I80; hind leg, 42; ear, II. Dr. Merriam (1. c.) gives total length $240 \mathrm{~mm}$. This must be a typographical error, and 440 is meant.

One specimen, Happy Lake.

24. Putorius streatori.

Putorius streatori. Merr., N. Am. Faun., No. II, I896, p. I3. This small weasel was met with at various places in our jour- 
neying through the mountains, but it was rather difficult to trap. Specimens vary somewhat in color, some being much darker than others, and not infrequently one fore foot would have considerable white displayed, while the other would be unicolor, like the back. All examples procured were in full summer pelage. It appeared to be more abundant than the preceding species.

Four specimens: Johnson's Ranch, Elwah River, I; Boulder Creek, r; Happy Lake, I; Boulder Lake, I.

25. Mephitis fœtulenta sp. nov.

General characters: In its outward appearance this species resembles $M$. spissigrada, Bangs, from British Columbia, but differs in the notched palate, the much shorter basi-occipital and other characters of the skull. From $M$. occidentalis of California, while the crania of the two species agree in structure, the longer known animal is at once separated by its wholly black tail. $M$. fotulenta seems to be between the two with characters of each.

Color: Black. Narrow line between the eyes, nauchal patch, stripe to shoulders, and two lateral stripes, being the division of shoulder stripe, extending to end of tail, white or yellowishwhite, the purity of the hue being a varying quantity. Towards the terminal portion the white extends over the entire width of the tail, and goes beyond the blunt black tip. Heels slightly covered with hair; claws long, especially on front feet, white with dark brown tips; claws of hind feet, dark reddish brown.

Cranial characters: Size of skull about the same as that of $M$. spissigrada. Pterygoid fossa much longer and basi-occipital narrower posteriorly, and shorter from the edge of the foramen magnum to its junction with the basi-sphenoid. Posterior edge of palate has a small notch at its center. Posterior portion of parietals constricted, and with an abrupt slope to the squamosal. Nasals longer and narrower than those of M. spissigrada, and the auditory bulloe larger both transversely and antero-posteriorly. Occiput to anterior end of nasals, $70 \mathrm{~mm}$.; nasals, I8; zygomatic width, 47; mastoid breadth, 40; length of pterygoid fossa, r6; basi-occipital, 12.

Type from the Lagune, near Port Angeles, Clallam County, Washington.

This skunk, which seems to be intermediate of the species found to the north and south of the Olympics, and possesses characters pertaining to each, is very abundant in the lower parts of the mountains, and the territory down to the sea. 
As many as sixty have been counted at one time, congregated on the beach at low tide hunting for soft shell clams, and hariou crustacea revealed by the receded waters. It is a handsome animal, the tail being large and bushy, with a great deal of white, which almost conceals the black hair, especially toward the end. In fact, the tail appears more white than black. The latter color is intensely jet, without any inclination to rusty or lightening in any place, and the hairs are very glossy.

Six specimens: The Lagune, near Port Angeles.

The figure exhibits lower surface of the skull of this subspecies of the natural sizes.

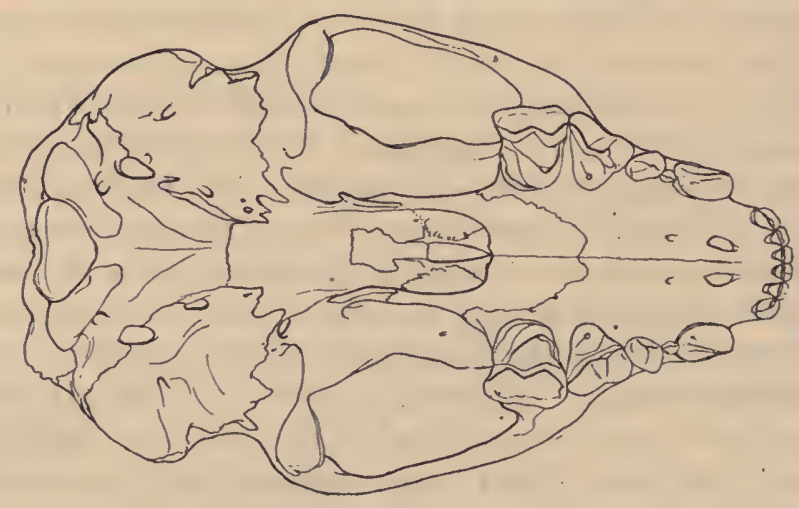

26. Spilogale olympica. Sp. nov.

General characters: Similar to $S$. p. latifroñs; but differing in measurements, and in the following described markings: The white on the forehead is long, comparatively narrow, diminishing gradually, and ending in a point posteriorly, and reaching nearly to a line drawn across head from base of ears. This mark in latifroñs is of nearly equal width throughout its length, and square posteriorly, ending just behind the eyes. The white stripe beginning behind the eyes, and running along the side of the back, is much broader, and more extensive in front of ears; a moderately broad white line commences just back of shoulder, and runs parallel with the lateral line above described, and crosses up to the back in front of hips. In S. phenax, this line is much broader, and widens greatly as it ascends to the back. The corresponding line in latifrons is merely a broad patch from the back to just in front of hips, and is 


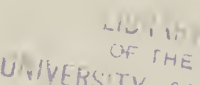

WAVERSTY of ILL'NOIS,

$$
\text { OIS, }
$$




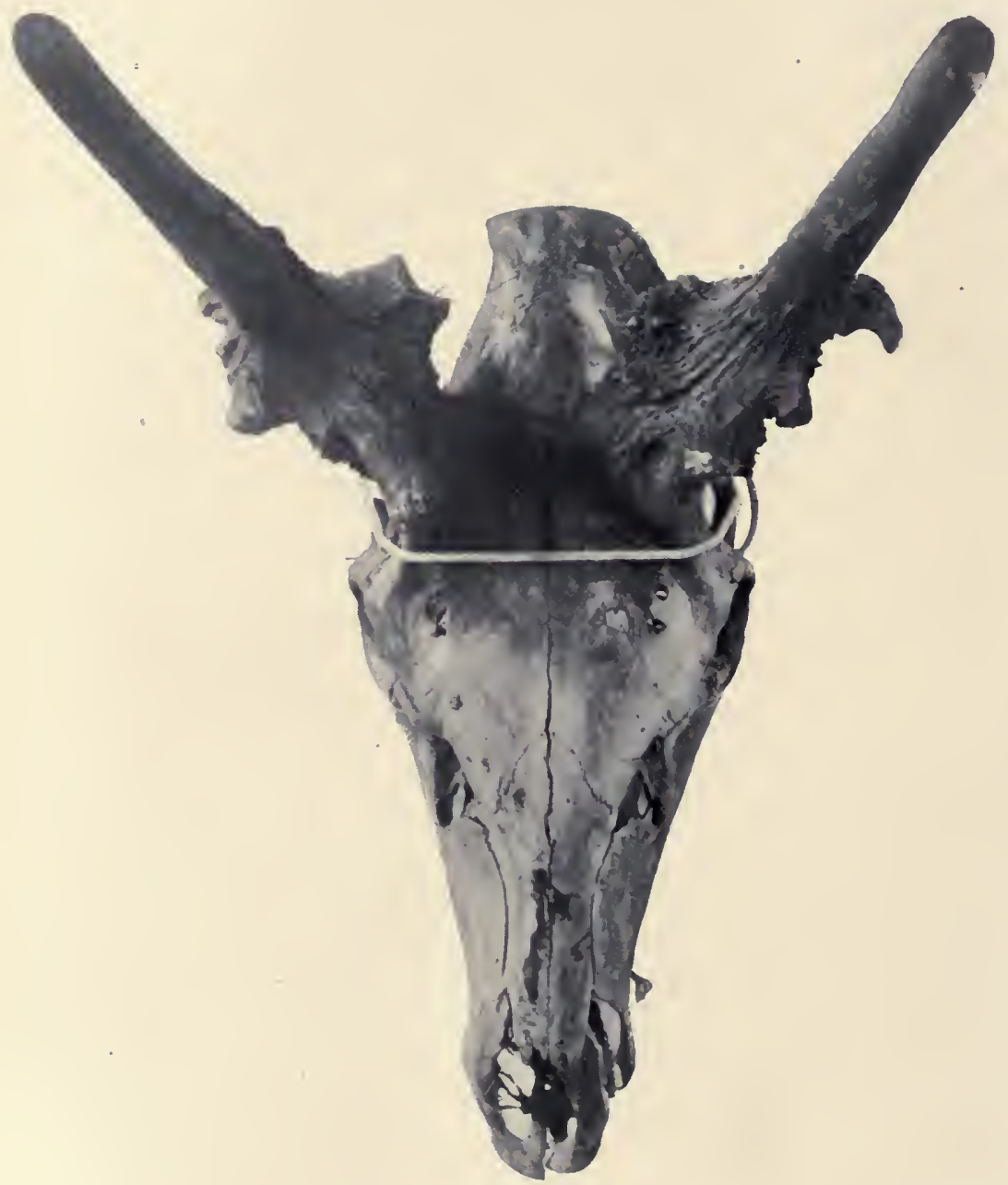

Cervus C. occidentalis.

YOUNG BULL. 
very broad and wide. Chin white, extending beyond corners of mouth. This mark varies in extent among individuals; soles of feet white, rest of markings similar to latifrous. The general color, however, is a clear black, without any brown tinge so perceptible in latifrons. The tail vertebræ is shorter, as is also the pencil, but the skull is larger. My comparison is made with the topotype (No. 573I7 o), from Eugene Oregon, 22d Nov., I 893, kindly loaned to me by Dr. Merriam.

Cranial characters : The skull of the topotype is badly damaged, making comparisons somewhat difficult, and so I give below measurements of six specimens of $S$. olympica, and also those given by Dr. Merriam of latifrons, from Roseburg, Oregon, and Chehalis County, Washington, in the N. Am. Faun., Pt. 4 (I89o.) The skull of the present species, compared with that of its nearest relative, is longer and broader, with a much greater curve of the outline of the occipital region, with a deep indentation at the posterior termination of the sagittal crest. This barely rises above the plane of the skull. The frontals are longer and the nasals shorter, with longer palatal bone, and pterygoid fossa. The bullæ are less inflated. The basi-occipital and basisphenoid are wanting in the latifrons skull, so no comparison can be made with them. The back molar is apparently nearer the palatal notch in latifrons than in olympica.

Type: Lake Southerland, Olympic Mts., Clallam County, Wash., r 8 th Oct., I 898 .

Measurements : Total length, 320. mm.; tail vert., I04; pencil, 60 ; hind foot, 4 I.

From S. phenax this new form differs in being smaller generally, the white stripes and markings narrower, shorter and less broader lateral line, widening as it goes to the back, a bushy tail, and differently proportioned skull.

Six examples: The Lagune, near Port Angeles, I; Lake Southerland, 5 .

The figures show upper and under side of skull of S. olympica, and for comparison the upper surface of $S$. latifrons, all of natural size. The very different dimensions of the two species can be seen at a glance. The greater breadth of S. latifrons and the occipital outline, merely a slight curve, is strongly contrasted with the rather narrow skull, and deeply emarginated occipital outline of $S$. olympica. 


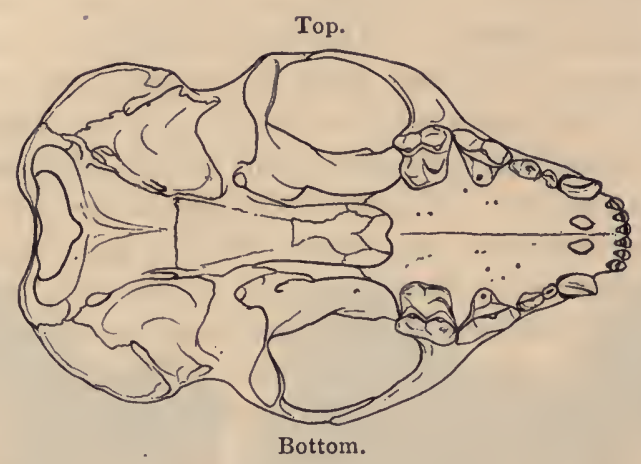

Sfilogale olympica.

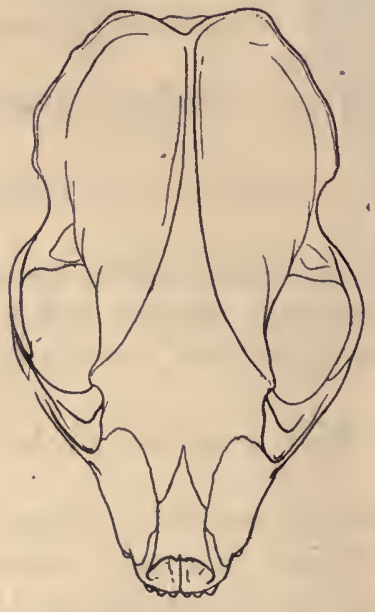

SPILOgale olympica.

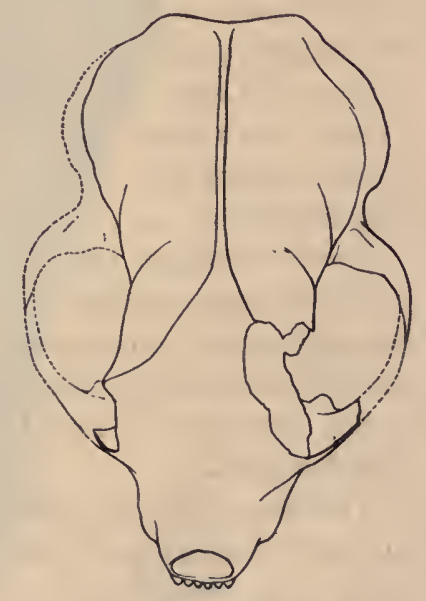

Spilogale latifrons. 
Basilar length from condyle to front of premaxillary... Basilar length from condyle to posterior rim of alveolus of middle incisor

Basilar length of hensel

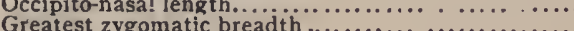

Greatest mastoid breadth

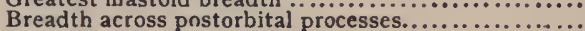

Least interorbital breadth.

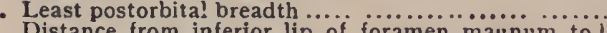
postpalatal notch .............................

Palatal length.......................................

Height of cranium from basi-sphenoid to parietal (at base of audital meatus) ..................

Height of cranium from palate to point between reatest breadth of brain case above or in front of inflated mastoids............................

Length of lateral series of teeth on alveoli ..................

Greatest breadth across molars ......................

Greatest breadth across canines.....................

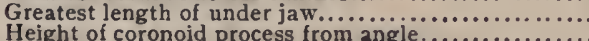

Height of coronoid process from angle............... to deepest part of postpalatal notch)

\section{MEASUREMENTS OF TEETH.}

Upper sectorial, greatest length of crown

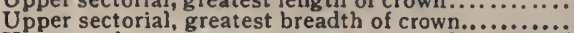
Upper molar, greatest antero-posterior diameter of crown (outer lobe)

Upper molar, greatest transverse diameter of crow.

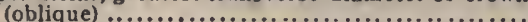

Upper molar. greatest transverse diameter of crown, from notch on outside.

Upper molar, greatest antero-posterior diameter of crown of inner lobe..........................

Lower sectorial, greatest length of crown

Lower sectorial, greatest breadth at middle.

Lower sectorial, greatest breadth of posterior jobe...

Combined length of upper sectorial and molar (on crown)

\begin{tabular}{|c|c|c|c|c|c|c|c|}
\hline \multicolumn{2}{|c|}{$\begin{array}{l}\text { S. p. lati- } \\
\text { frons. }\end{array}$} & \multirow[b]{2}{*}{$\dot{\ddot{z}}$} & \multicolumn{3}{|c|}{$\begin{array}{l}\text { S. p.olym- } \\
\text { pica. }\end{array}$} & \multirow[b]{2}{*}{$\begin{array}{l}\dot{2} \\
\dot{z}\end{array}$} & \multirow[b]{2}{*}{$\begin{array}{l}0 \\
\dot{0} \\
\dot{z}\end{array}$} \\
\hline 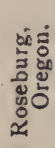 & 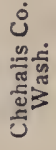 & & $\begin{array}{l}\dot{3} \\
\dot{\delta} \\
z\end{array}$ & $\begin{array}{l}\text { in } \\
\dot{0} \\
z\end{array}$ & $\dot{8}$ & & \\
\hline & .52 .3 & 55. & 57. & 54. & 57. & 54. & $\cdots$ \\
\hline & 51.5 & 54. & 56. & 53. & 56. & 53. & $\ldots$ \\
\hline & $\begin{array}{l}46.2 \\
4^{8.8}\end{array}$ & $\begin{array}{l}50 . \\
51 .\end{array}$ & $\begin{array}{l}52.5 \\
54 .\end{array}$ & $\begin{array}{l}47 . \\
50 .\end{array}$ & $\begin{array}{l}51 . \\
52 .\end{array}$ & $\begin{array}{l}88 \\
51 .\end{array}$ & \\
\hline & $\begin{array}{l}34.2 \\
30.3\end{array}$ & $\begin{array}{l}34 . \\
33 .\end{array}$ & $\begin{array}{l}37 . \\
30 .\end{array}$ & $\begin{array}{l}34 . \\
30 .\end{array}$ & $\begin{array}{l}35 . \\
31 .\end{array}$ & $\begin{array}{l}37 . \\
31 .\end{array}$ & $\begin{array}{l}38 . \\
32 .\end{array}$ \\
\hline & 18. & I8. & 18. & 17. & 17.5 & 18 & 20. \\
\hline $\begin{array}{l}15.3 \\
15.6\end{array}$ & $\begin{array}{l}15 . \\
15.5\end{array}$ & $\begin{array}{l}16 . \\
16 .\end{array}$ & $\begin{array}{l}16 . \\
17 .\end{array}$ & $\begin{array}{l}16 . \\
16 .\end{array}$ & $\begin{array}{l}15 . \\
16 .\end{array}$ & $\begin{array}{l}15 . \\
16 .\end{array}$ & $\begin{array}{l}\text { I5. } \\
\text { I7. }\end{array}$ \\
\hline & 27.5 & 27. & 30. & 27. & 30. & 29. & .... \\
\hline 8.5 & I9.3 & 20. & 22. & 19. & 20. & 19. & 20. \\
\hline 14.5 & 16.5 & 20. & 20. & 17. & I8. & 18. & 17. \\
\hline 13 & 14.4 & 15. & 15. & 15. & 15. & 15. & 16. \\
\hline 25 & 25.5 & 32. & 32. & 29. & 29. & 28. & 31. \\
\hline 16.5 & 16.8 & 18. & 20. & I9. & 18. & 18. & 18. \\
\hline $\begin{array}{l}19.5 \\
11.5\end{array}$ & $\begin{array}{l}20 . \\
11.3\end{array}$ & $\begin{array}{l}20 . \\
13 .\end{array}$ & $\begin{array}{l}21 . \\
13 .\end{array}$ & $\begin{array}{l}20 . \\
13 .\end{array}$ & $\begin{array}{l}21 . \\
13 .\end{array}$ & $\begin{array}{l}21 . \\
14 .\end{array}$ & $\begin{array}{l}21 . \\
14 .\end{array}$ \\
\hline & $\begin{array}{l}34.8 \\
15.8\end{array}$ & $\begin{array}{l}36 . \\
16 .\end{array}$ & $\begin{array}{l}37 . \\
18 .\end{array}$ & $\begin{array}{l}33 . \\
15 .\end{array}$ & $\begin{array}{l}37 . \\
16 .\end{array}$ & $\begin{array}{l}36 . \\
17 .\end{array}$ & $\begin{array}{l}36 . \\
17 .\end{array}$ \\
\hline & 11.7 & II . & II. & 11. & 13. & II. & 12.5 \\
\hline & 6.3 & 7. & 6.5 & 6.6 & 6.5 & 7. & 6.4 \\
\hline & 4.2 & 5. & 4.2 & 4. & 4. & 4. & 4.2 \\
\hline & 4.9 & 5. & 5. & 5. & 5. & 5. & 5. \\
\hline & 6.2 & 6.3 & 6.3 & 6.5 & 6. & 6.3 & 7. \\
\hline & 4.8 & 5. & 5. & 5. & 5. & 5. & 6. \\
\hline & 3.8 & 4. & 4. & 4. & 4. & 4. & 4.5 \\
\hline & 7. & 7.6 & 8. & 7. & $7 \cdot 5$ & $7 \cdot 5$ & 7.8 \\
\hline & 2.0 & 3. & 3. & 3. & 3. & 3. & 3.2 \\
\hline & 10.4 & II. & 11. & 10. & 11. & II. & II. \\
\hline
\end{tabular}




\section{ORDER INSECTIVORA.}

\section{FAM. SORICID死.}

27. Sorex vagrans.

Sorex vagrans. Baird, Mamm. N. Am., vol. viii., I857, p. I 5, pl. xxvi.

This shrew was quite numerous and would frequently be found in the traps set for mice and other larger animals. It seemed to be equally abundant along the banks of the Elwah River and on the tops of the mountains, as about half the specimens were taken at Happy and Boulder Lakes. The color of the different examples do not vary; one only being very dark, a kind of blackish-brown, this probably being winter pelage, and the total length ranged from 92 to $110 \mathrm{~mm}$., the latter a rather exceptional size.

Twelve specimens: 6, Johnson's Ranch, Elwah River; 6, Happy Lake.

28. Sorex setosus, sp. nov.

Two rather large shrews were procured in the vicinity of $\mathrm{Happy}$ Lake which differ from any I have ever seen or known to be described, in having a bunch of stiff bristles on a rather bare spot on the sides of the body about half-way between the fore and hind legs. These may cover a gland. On the animal, when in' the flesh, they were even more conspicuous than they now are in the skin, and could be moved about and spread open quite freely. This shrew may be described as follows:

General character: Larger than either S. vagrans or S. obscurus, similar in the color of the back but with brighter sides, and greyish-white beneath with a tint of buff. Third unicuspid smaller than fourth. Tail about one-fifth shorter than body and head.

Color: Entire upper parts light cassell brown with a greyish sheen upon it, which causes it to vary in depth according to the light in which the specimen is held. Flanks, brownish ochre, with a spot denuded of fur in the center, covered by a bunch of buff-colored bristles. Under parts greyish-white, almost silvery in certain lights, tinted with buff. Legs and feet flesh color. Tail dark brown above, yellowish-white beneath.

Cranial characters: Skull $18 \mathrm{~mm}$. from occiput to end of nasals ; greatest width of brain case, $8 \mathrm{~mm}$. Palate wide poste- 
riorly and $7 \mathrm{~mm}$. in length. Pterygoids $3 \mathrm{~mm}$. long, their fossa wide. Length of basi-sphenoid and basi-occipital, $4.5 \mathrm{~mm}$. First and second unicuspids largest and nearly equal, third and fourth much smaller, the fourth larger than the third. Molars large, combined length along alveolus, $3 \mathrm{~mm}$.

Compared with the skull of S. vagrans, that of this species is longer, with the brain case broader anteriorly, wider palate and much longer pterygoids. Unicuspids much larger.

Compared with skull of $S$. obscurus, the brain case is broader and longer as are also the nasals. The palate is narrower, the unicuspids are considerably larger and the premaxillaries descend to the symphysis at a much more acute angle. The difficulty of obtaining perfect skulls of these small mammals make a minute comparison usually impossible, as often the occipital region is wanting, or the brain case crushed in the traps, and out of five specimens of obscurus there is but one fairly complete skull. The species, however, are quite different. Total length, $120 \mathrm{~mm}$; tail, 54; hind leg, I 3 .

Type: Happy Lake, Olympic Mountains, Clallam County Washington.

Two specimens from Happy Lake.

The figures exhibit outline of upper jaw and profile of tooth row, and the upper tooth row looked at from above. They are "ábout five and a half times greater than natural size.

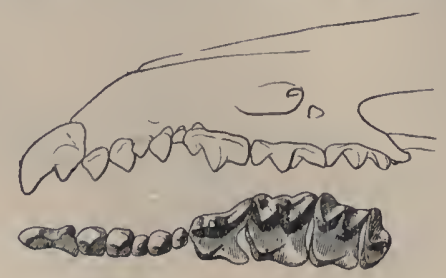

FAM. TALPID压.

29. Scapanus townsendi.

Scalops townsendi. Bach. Journ. Acad. Nat. Scien., Phil., 1839, vol. viii., pt. I, p. 58 .

One specimen only of this large mole was obtained, found upon the Solduck trail leading to the Hot Springs, killed by some animal, possibly a hawk. From the locality it ought to be $S$. orarius True, but its large size would seem to show that it must be 
placed with S. townsendi. The color is black with a silvery gloss, tinted in some lights with a coppery luster. Feet and tail white. Total length, $206 \mathrm{~mm}$. ; tail, 27; hind leg, 27; length of skull from occiput to end of nasals, $40 \mathrm{~mm}$; mastoid breadth, 19; length of palate from inside of incisor, 17 ; greatest zygomatic breadth, 15 .

\section{ORDER CHIROPTERA.}

\section{FAM. VESPERTILIONIDA.}

30. Myotis yumanensis saturatus.

Myotis yumanensis saturatus. Miller, N. Am. Faun., No. I3, I897, p. 68.

At our Boulder Lake camp, three or four bats were seen at dusk diving about in the air, and Mr. Akeley succeeded one evening in shooting two, only one of which he secured. It proved to be the subspecies described by Miller (1. c.). Quite a small bat with glossy dark fur, yellowish-brown for the most part, but appearing black in some lights. On the Elwah River, near a place called the Devil's Elbow, was a colony of bats inhabiting a large hole or small cave in the rock. Unfortunately we did not secure any of them, so I cannot say if they were the same as the present subspecies. With the exception of these two localities we did not meet with any of these animals. 


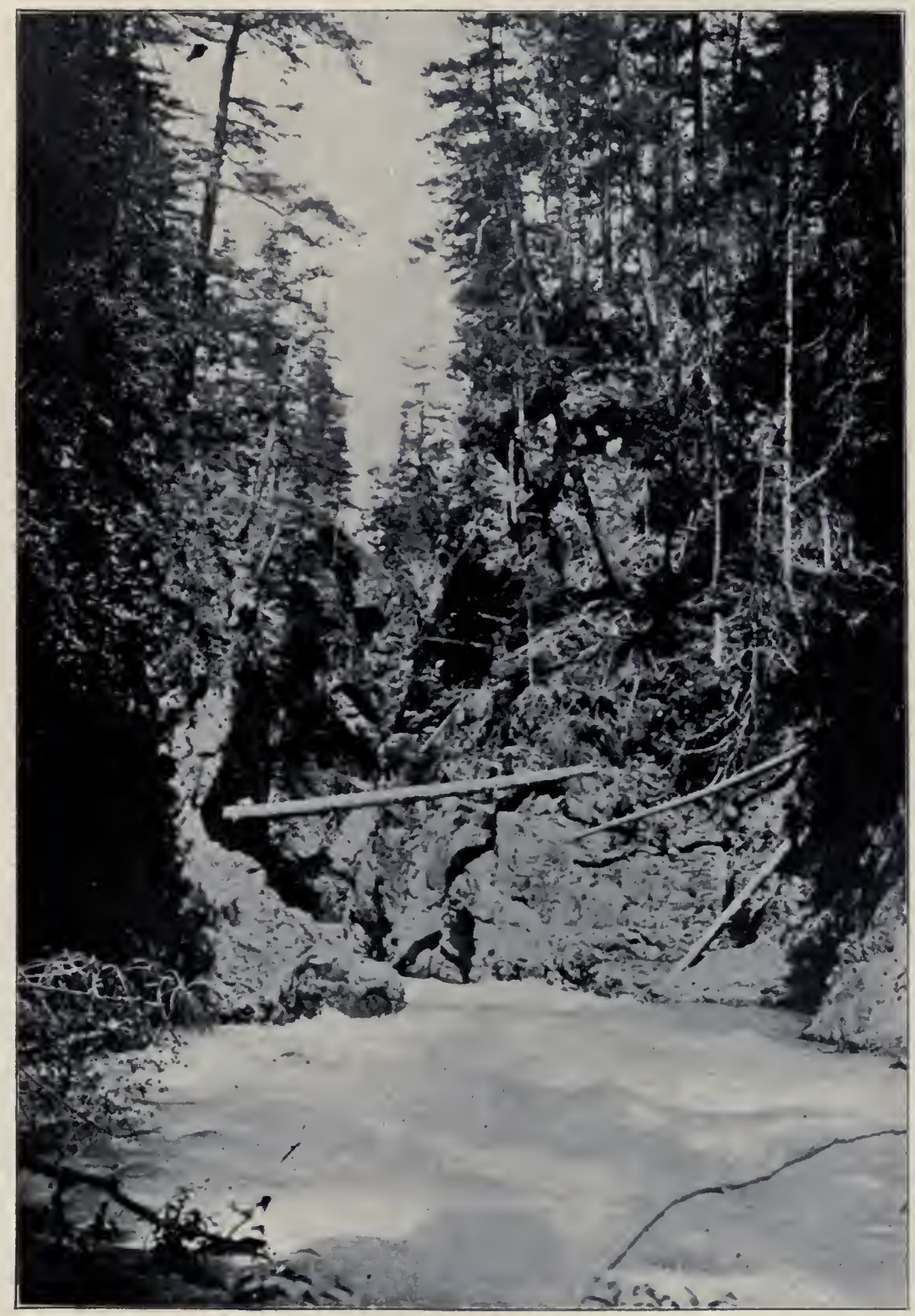

Entrance to Canon of the Elwah. 
LBSTARY

UNIVERSITY OF ILLINOIS, 



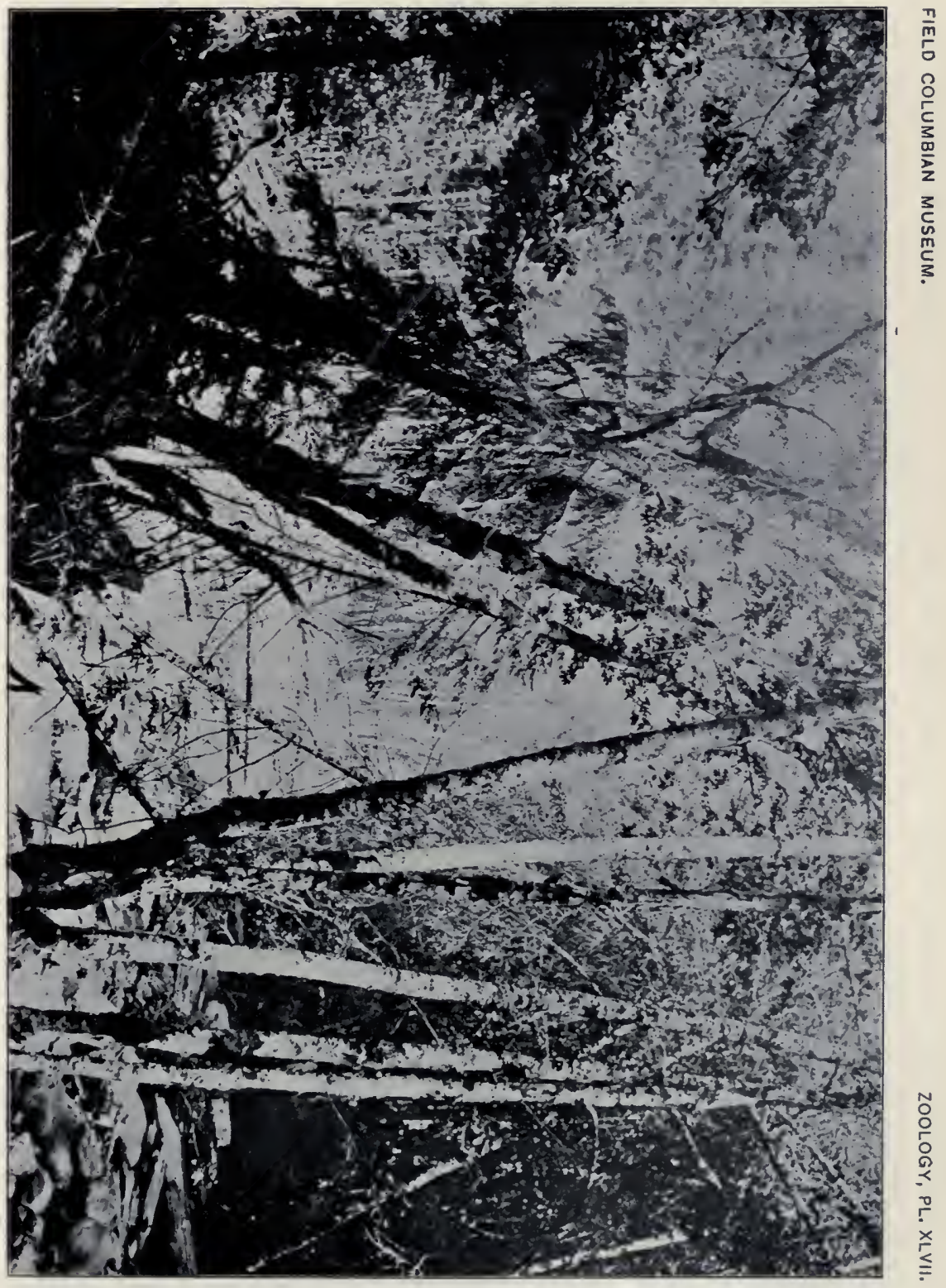


LIERARY

UNIIYERSITY of ILLINOIS. 
Lin: i

JWYVERSITY of ILLINOIS. 


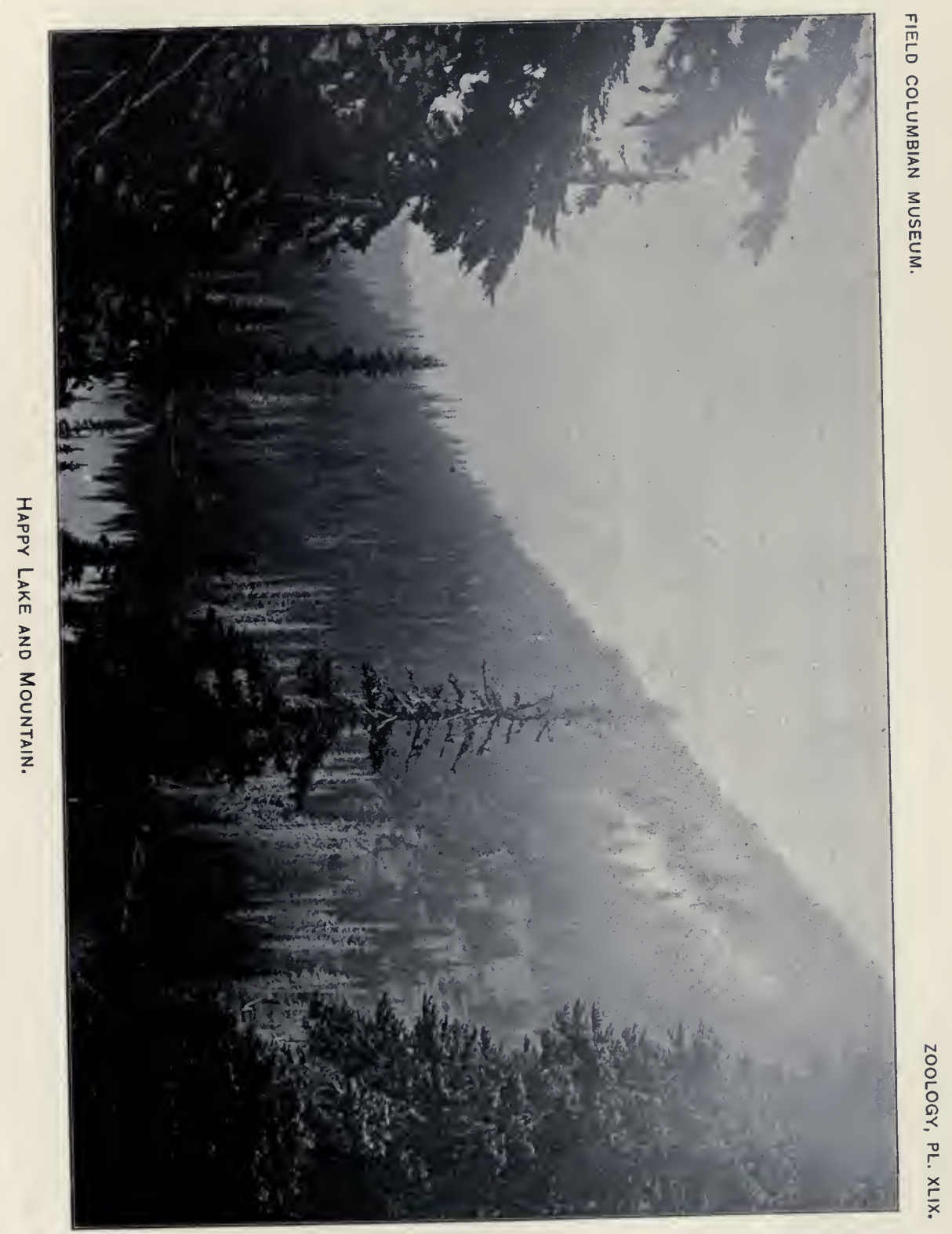





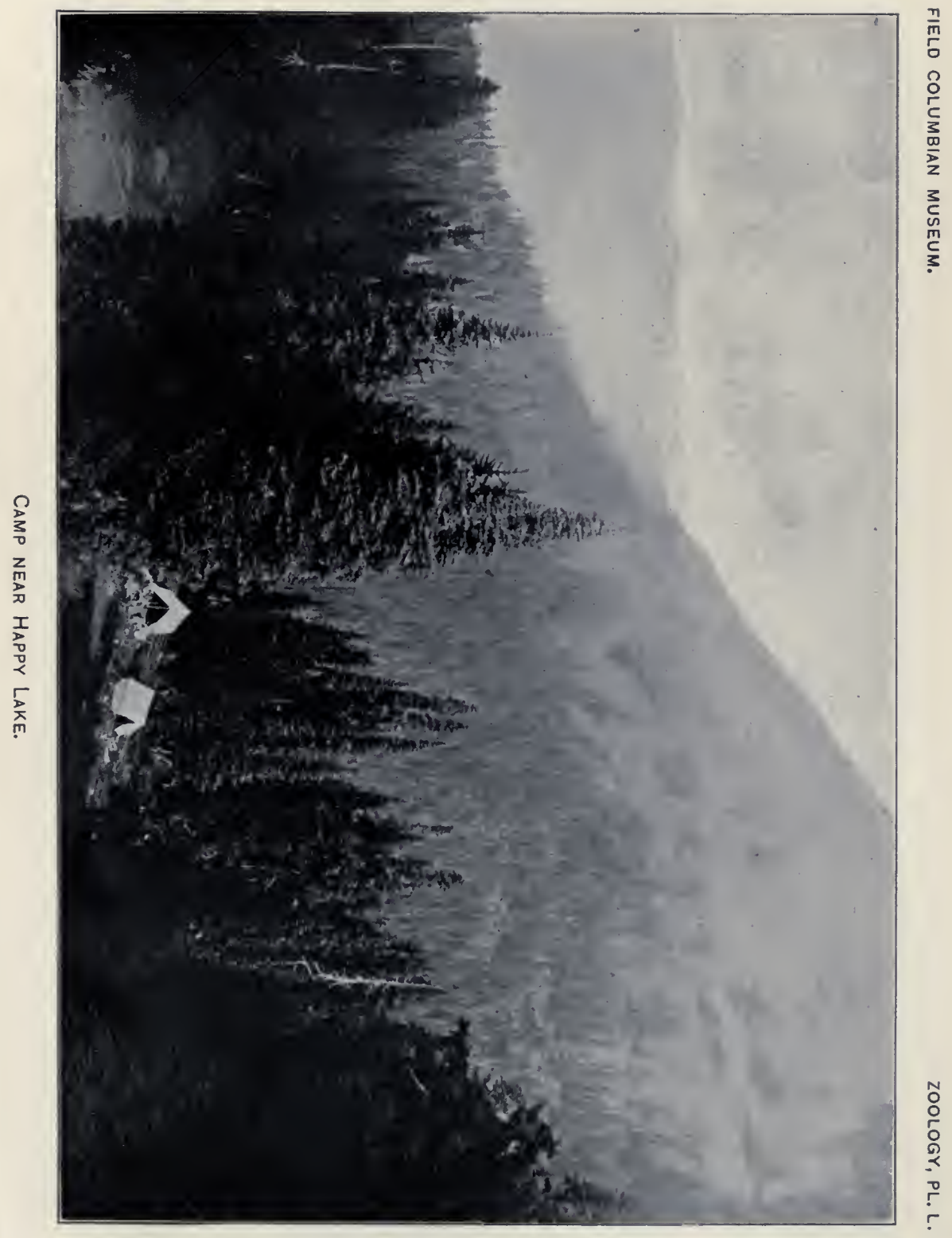





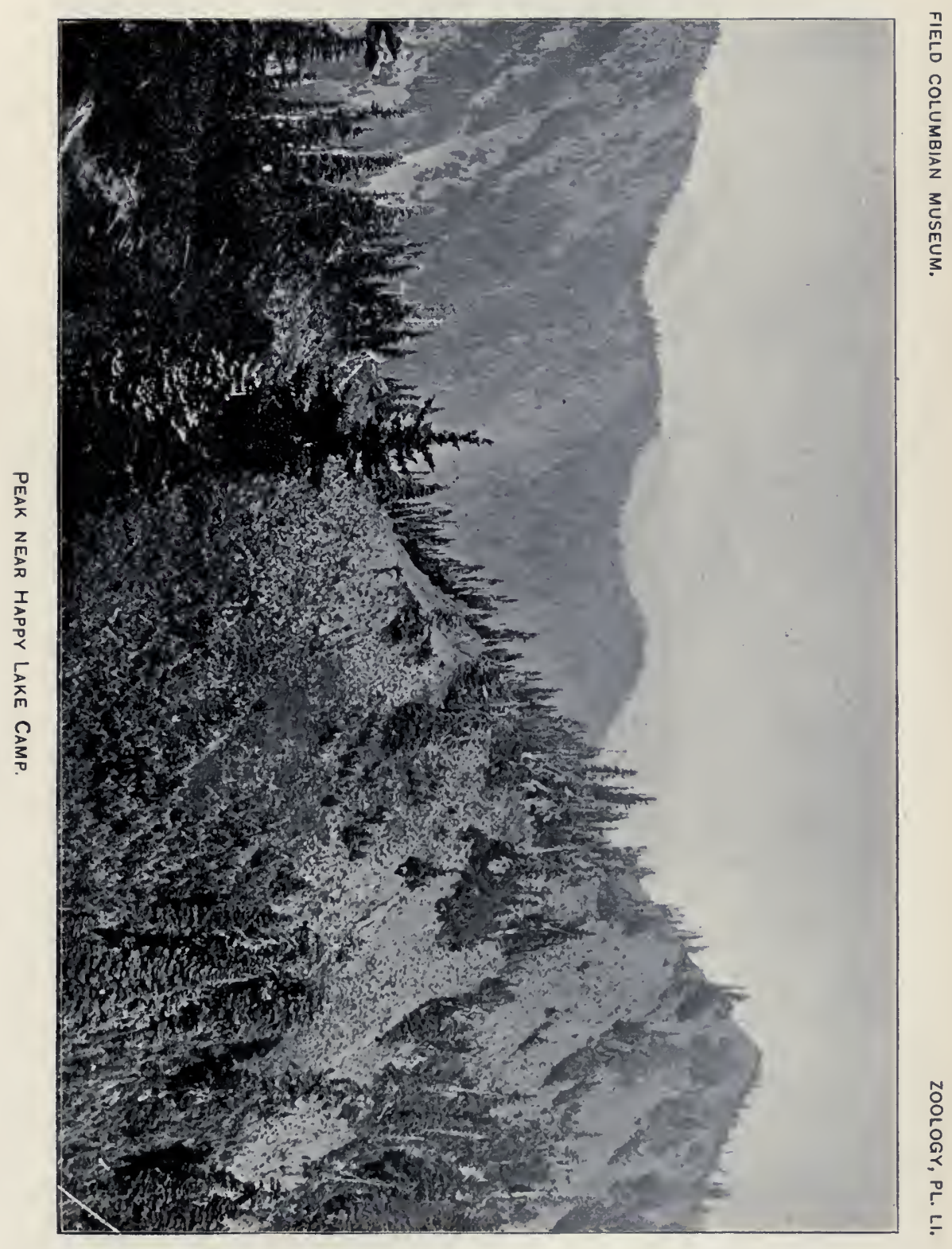


LIERTity

UNIVERSITY of ILLINOIS. 


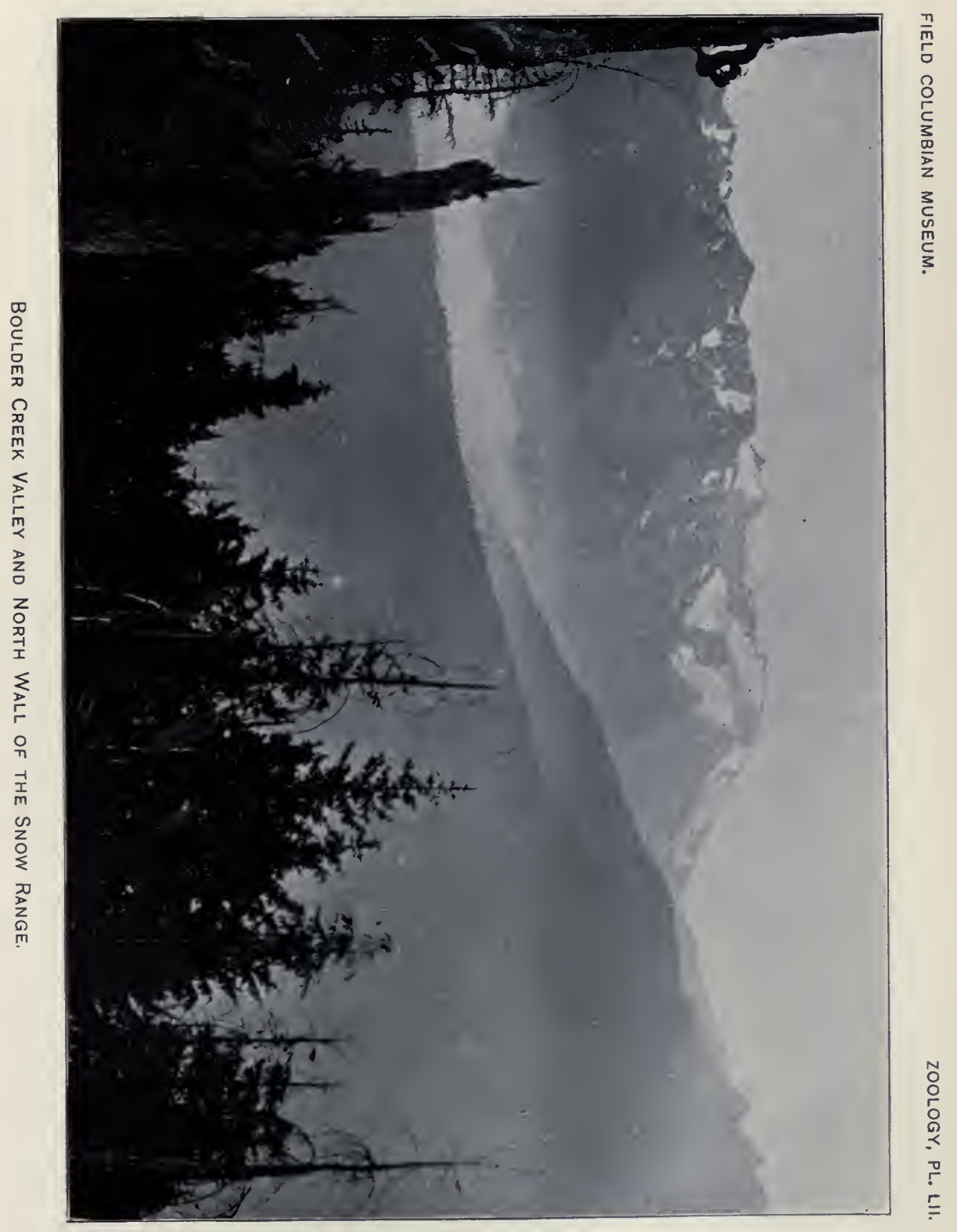


Lin:木 I,

WWYERSITY of ILLINOIS, 


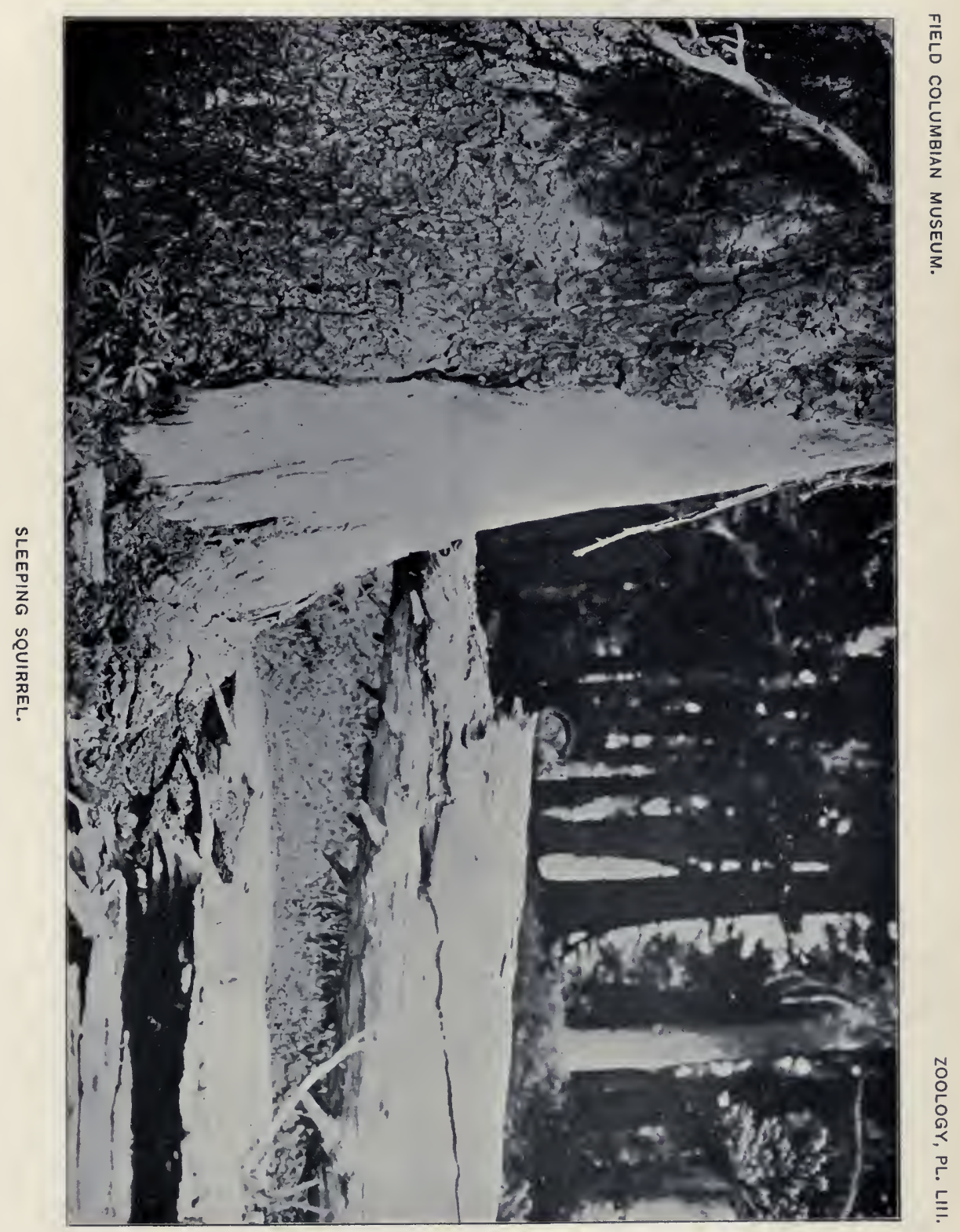





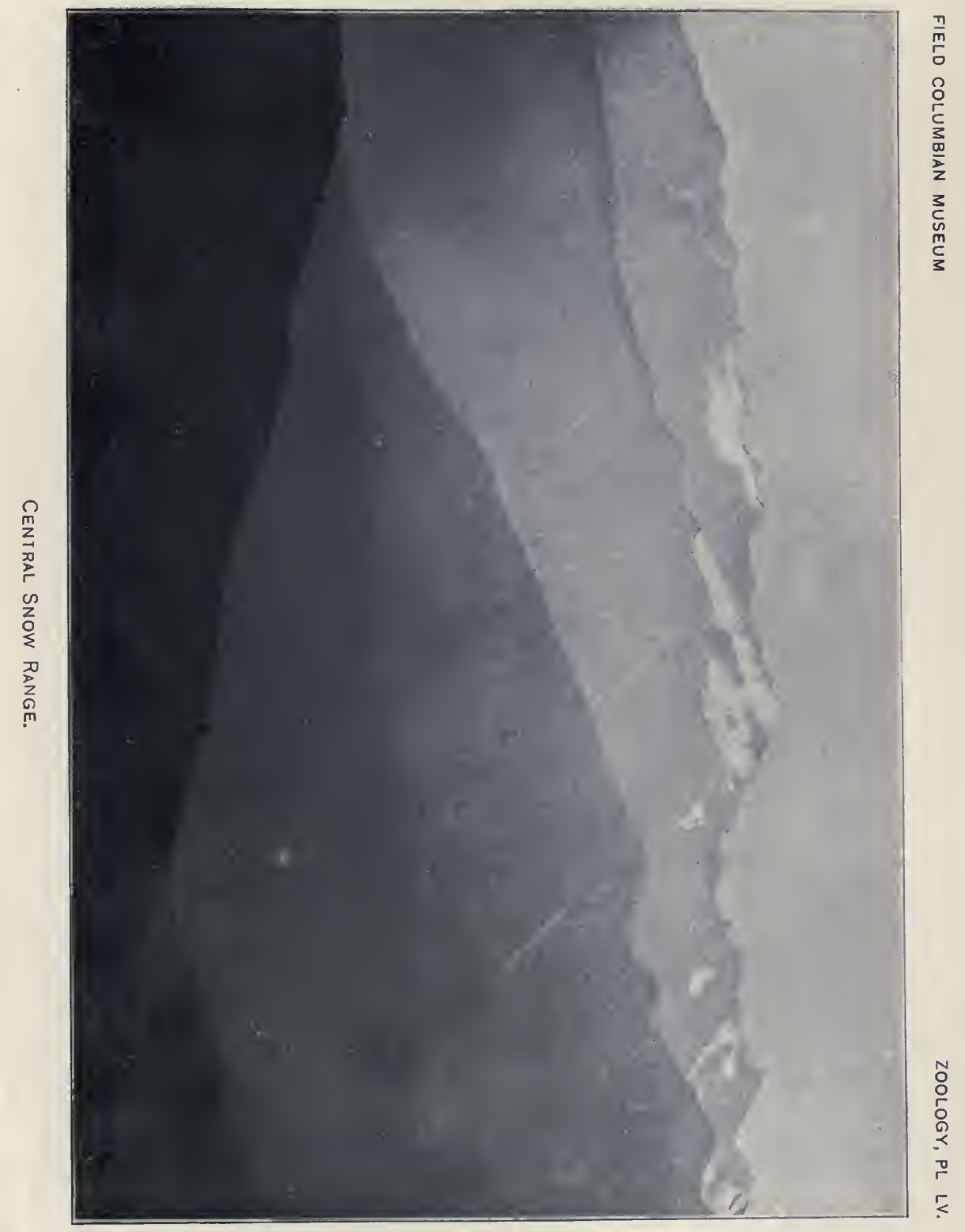


W I IRS

(IW YEYGTTY of ILLNOIS. 




$$
4
$$





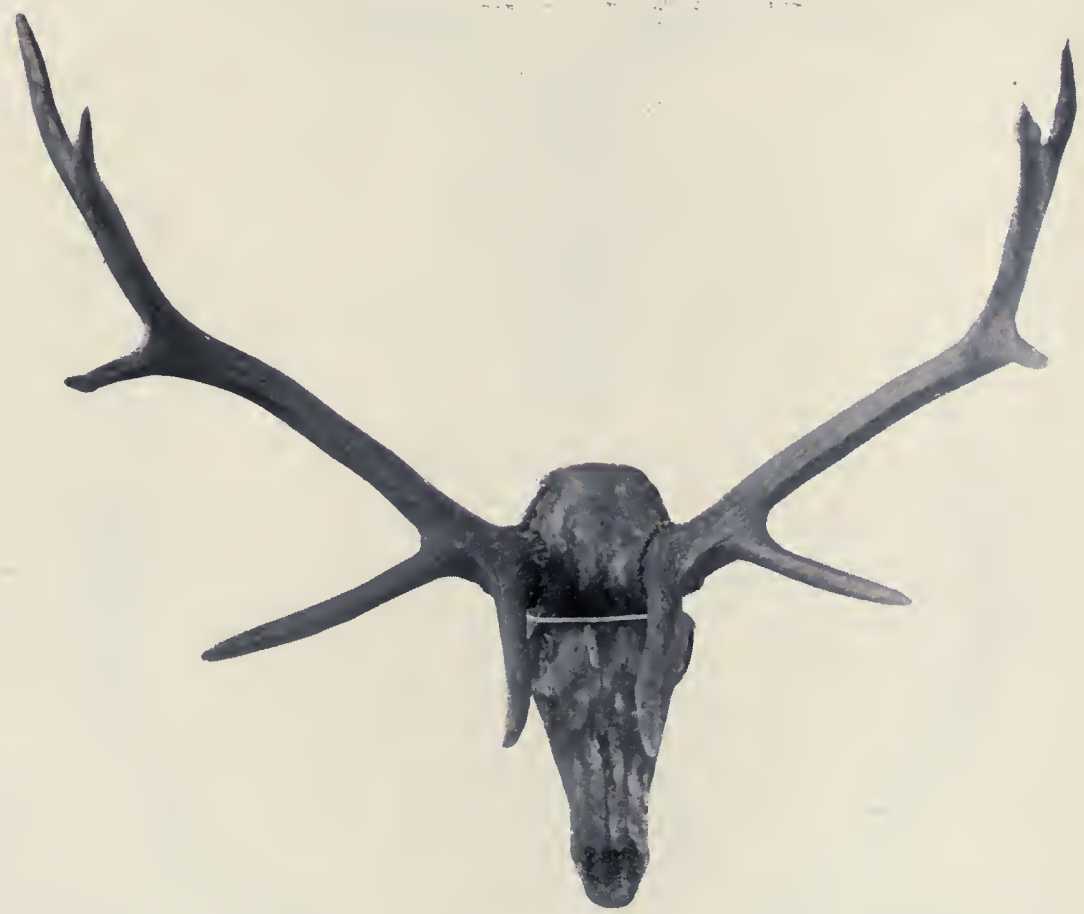

Cervus C. CCCIDENTALIS No. 2 
WhitKSITY of ILLINOIS. 


$$
\frac{}{2}
$$





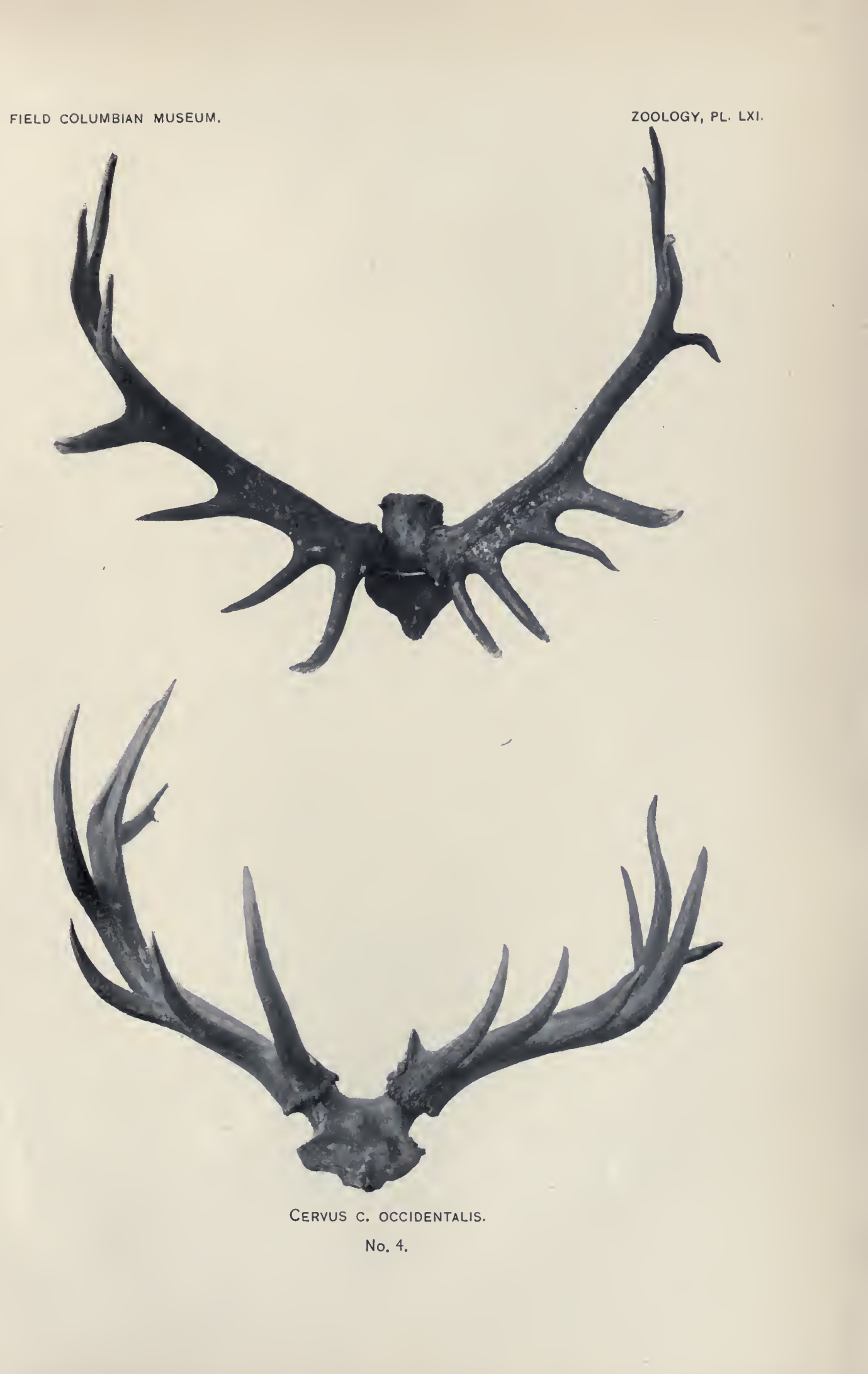








$$
\text { sestitis }
$$

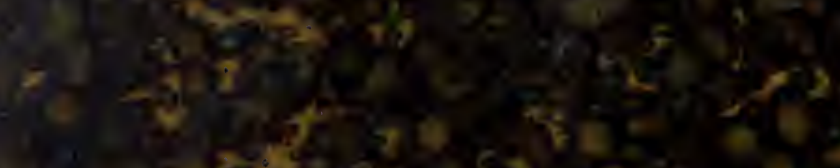

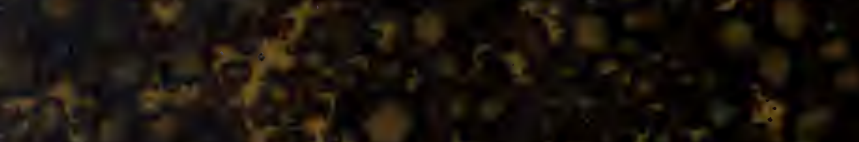

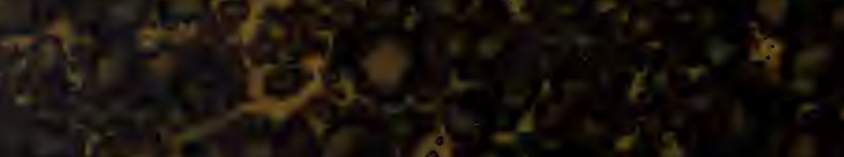

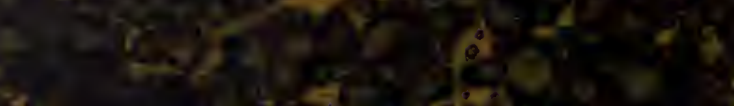

3

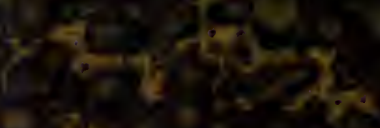

7.

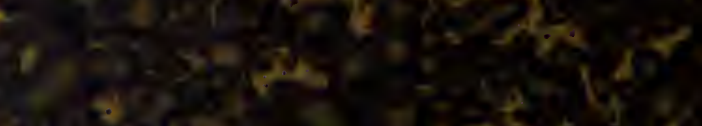

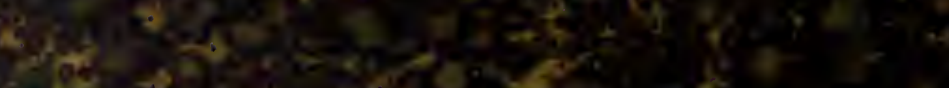

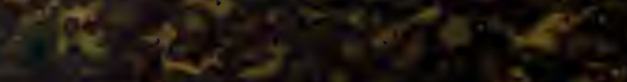

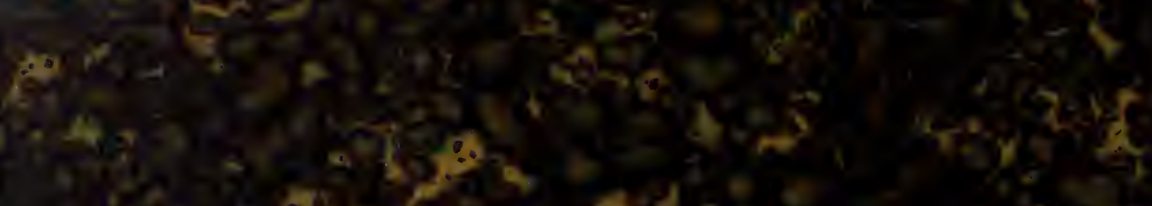

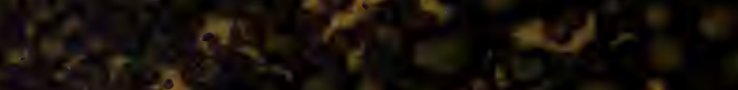

3

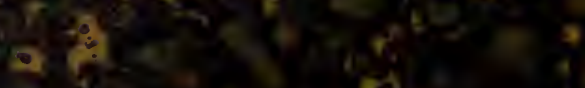
$\operatorname{ran} 4$
8

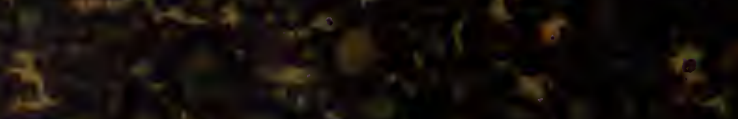

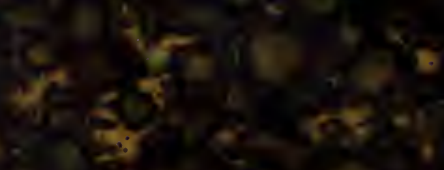

98

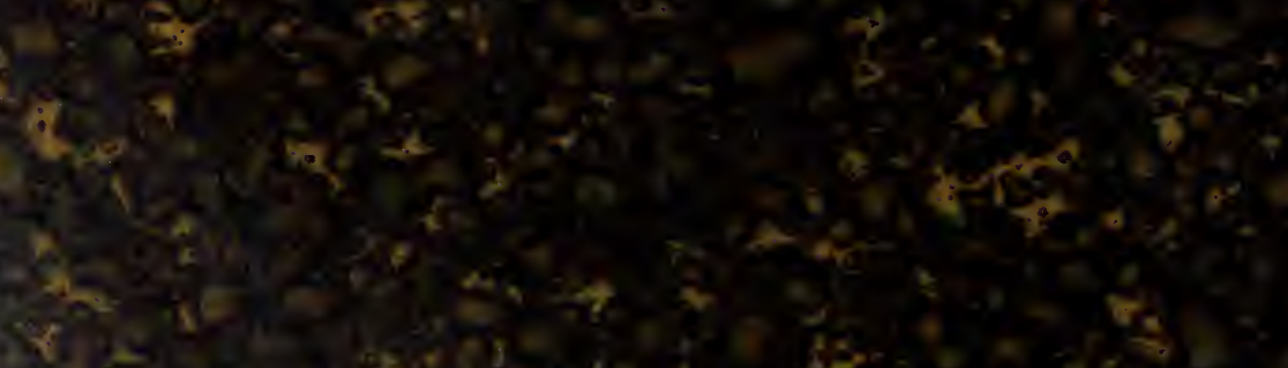

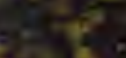

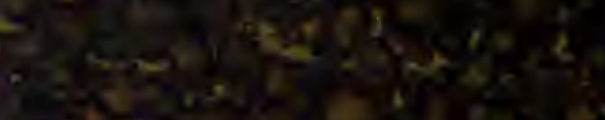

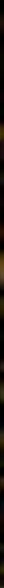

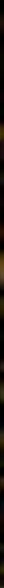

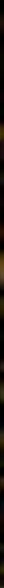

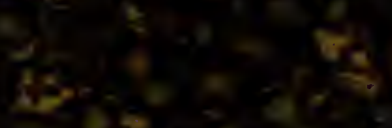

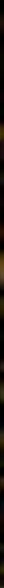




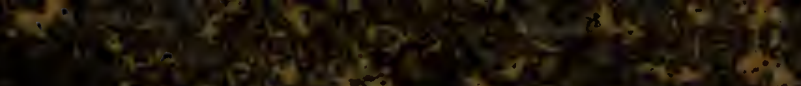

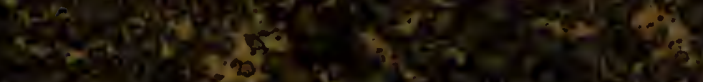

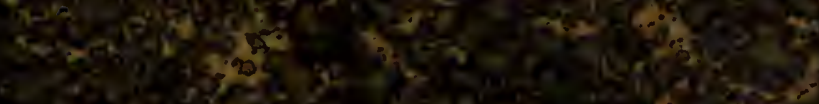

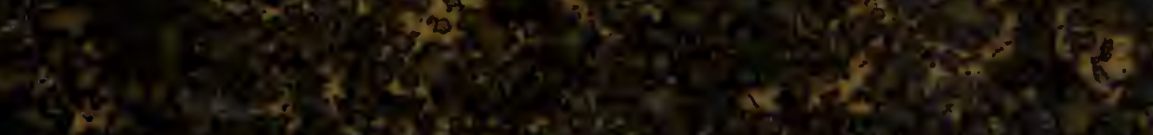

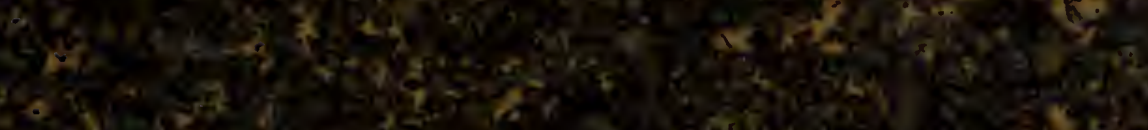

t.

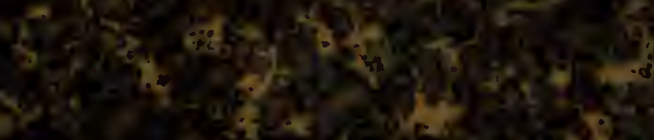

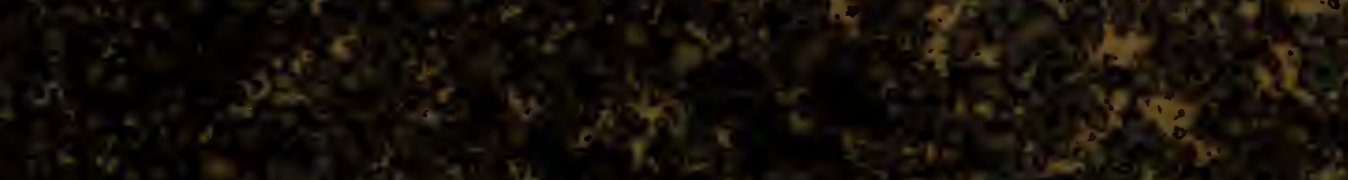

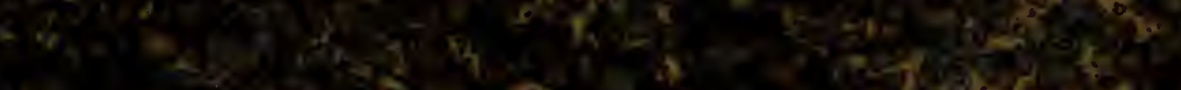

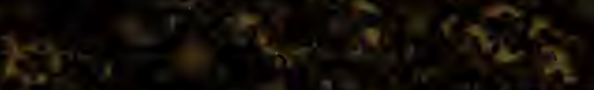

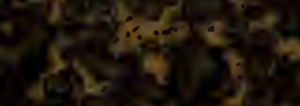
a.

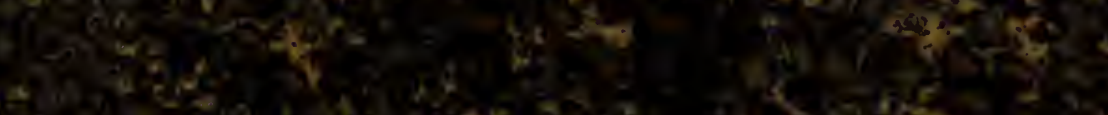

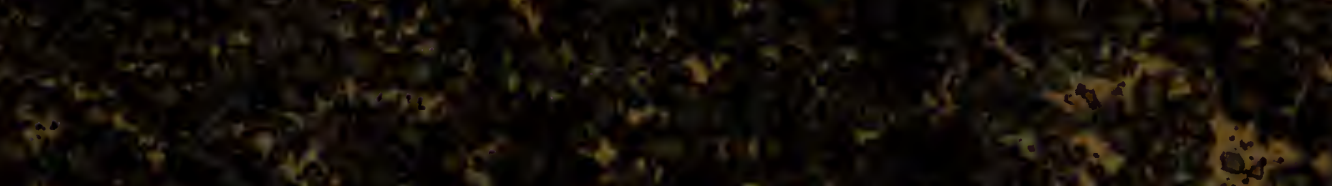

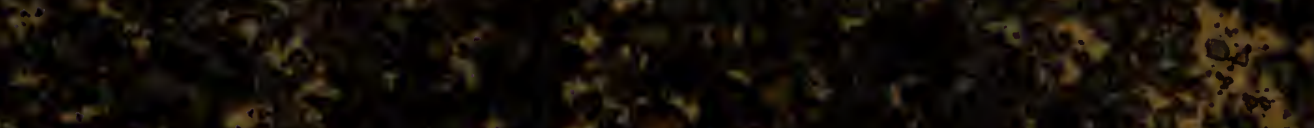

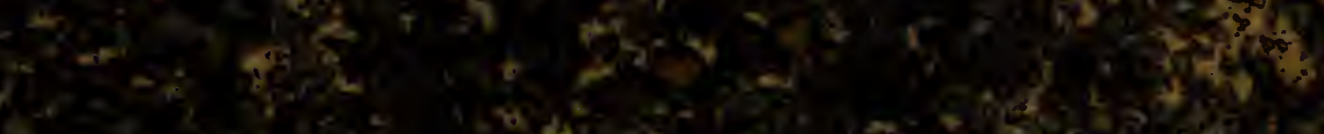

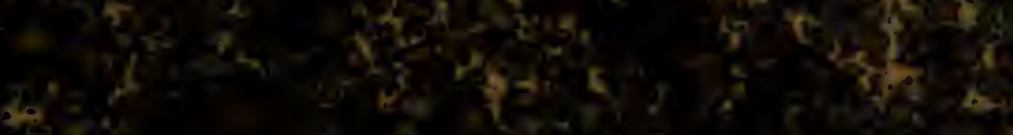

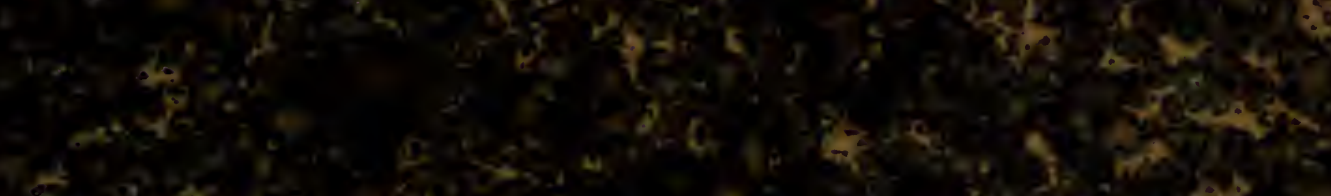

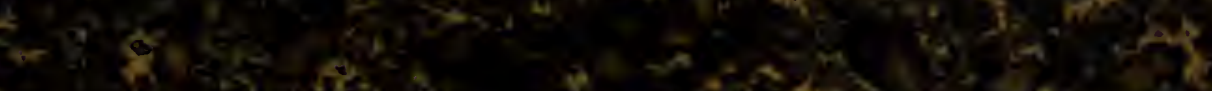

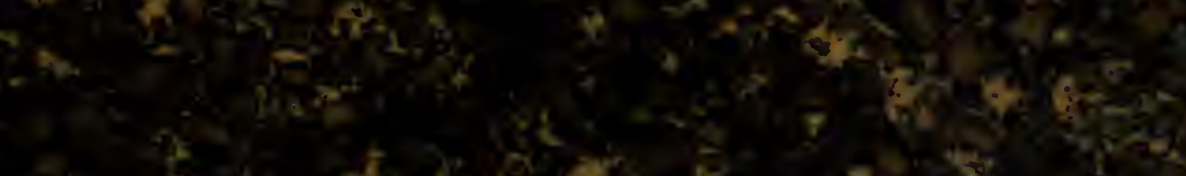
2.

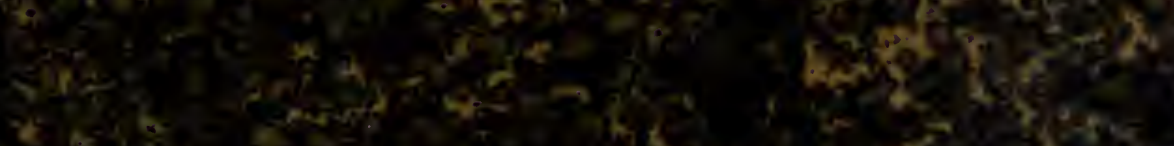

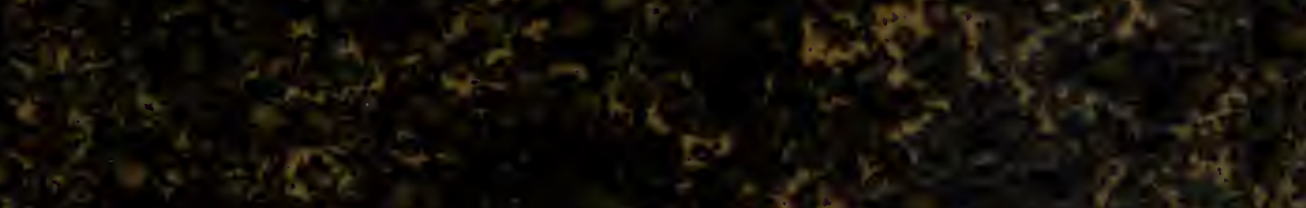

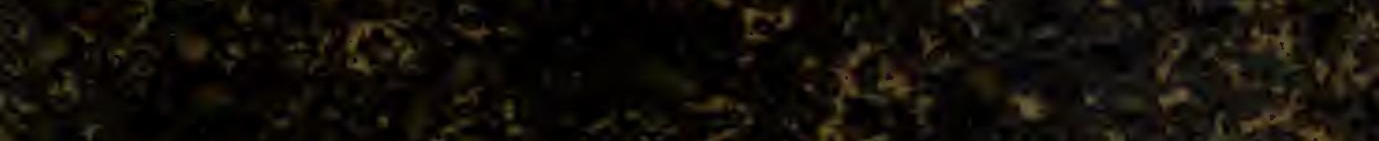

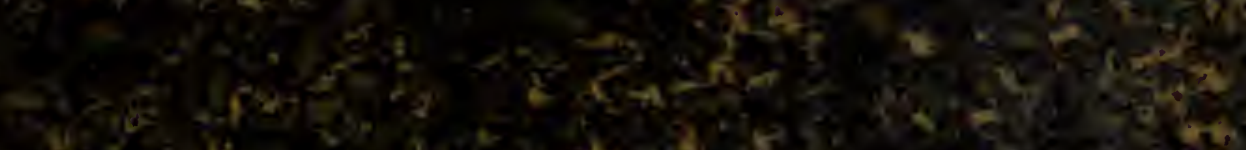

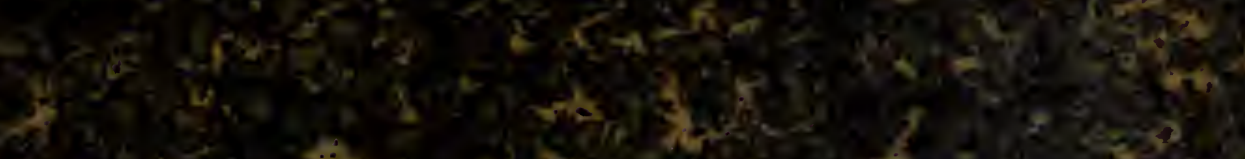

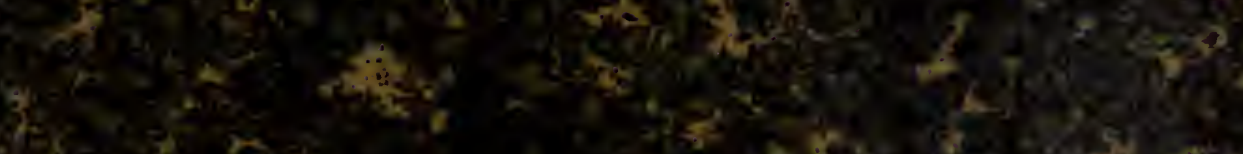

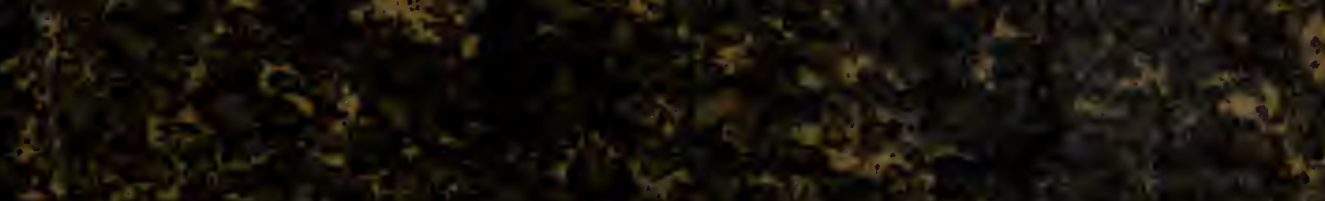


